\title{
An Overview of the Molecular Mechanisms Contributing to Musculoskeletal Disorders in Chronic Liver Disease: Osteoporosis, Sarcopenia, and Osteoporotic Sarcopenia
}

\author{
Young Joo Yang ${ }^{1,2} \mathbb{D}$ and Dong Joon Kim ${ }^{1,2, * \mathbb{D}}$ \\ 1 Department of Internal Medicine, Hallym University College of Medicine, Gangwon-do, \\ Chuncheon 24252, Korea; yjyang@hallym.ac.kr \\ 2 Institute for Liver and Digestive Diseases, Hallym University, Gangwon-do, Chuncheon 24253, Korea \\ * Correspondence: djkim@hallym.ac.kr
}

check for updates

Citation: Yang, Y.J.; Kim, D.J. An Overview of the Molecular

Mechanisms Contributing to

Musculoskeletal Disorders in Chronic

Liver Disease: Osteoporosis,

Sarcopenia, and Osteoporotic

Sarcopenia. Int. J. Mol. Sci. 2021, 22,

2604. https://doi.org/10.3390/

ijms22052604

Academic Editor: Giuseppe D'Antona

Received: 31 January 2021

Accepted: 2 March 2021

Published: 5 March 2021

Publisher's Note: MDPI stays neutral with regard to jurisdictional claims in published maps and institutional affiliations.

Copyright: (c) 2021 by the authors. Licensee MDPI, Basel, Switzerland. This article is an open access article distributed under the terms and conditions of the Creative Commons Attribution (CC BY) license (https:// creativecommons.org/licenses/by/ $4.0 /$ )

\begin{abstract}
The prevalence of osteoporosis and sarcopenia is significantly higher in patients with liver disease than in those without liver disease and osteoporosis and sarcopenia negatively influence morbidity and mortality in liver disease, yet these musculoskeletal disorders are frequently overlooked in clinical practice for patients with chronic liver disease. The objective of this review is to provide a comprehensive understanding of the molecular mechanisms of musculoskeletal disorders accompanying the pathogenesis of liver disease. The increased bone resorption through the receptor activator of nuclear factor kappa (RANK)-RANK ligand (RANKL)-osteoprotegerin (OPG) system and upregulation of inflammatory cytokines and decreased bone formation through increased bilirubin and sclerostin and lower insulin-like growth factor-1 are important mechanisms for osteoporosis in patients with liver disease. Sarcopenia is associated with insulin resistance and obesity in nonalcoholic fatty liver disease, whereas hyperammonemia, low amount of branched chain amino acids, and hypogonadism contributes to sarcopenia in liver cirrhosis. The bidirectional crosstalk between muscle and bone through myostatin, irisin, $\beta$-aminoisobutyric acid (BAIBA), osteocalcin, as well as the activation of the RANK and the Wnt/ $\beta$-catenin pathways are associated with osteosarcopenia. The increased understandings for these musculoskeletal disorders would be contributes to the development of effective therapies targeting the pathophysiological mechanism involved.
\end{abstract}

Keywords: osteoporosis; sarcopenia; osteosarcopenia; chronic liver disease

\section{Introduction}

Osteoporosis is characterized by low bone mass, the deterioration of bone macro-and micro-architecture, and is a common complication observed in patients with chronic liver disease [1]. The prevalence of osteoporosis in chronic liver disease patients is $10-40 \%$, which is higher than in the general population without liver disease [1]. The presence of osteoporosis in patients with liver disease adversely affects their clinical outcomes in terms of quality of life, survival, and liver-related complications, regardless of etiology and severity [1,2]. Since sarcopenia was first proposed as the concept of age-related loss of muscle mass in 1989, numerous studies have demonstrated its molecular pathogenesis and clinical implications, especially in the context of chronic liver disease, as the liver is an important organ for carbohydrate, protein, and lipid metabolism, whose deterioration results in protein supply dysregulation and hyperammonemia, inevitably influencing skeletal muscle homeostasis [3-9]. Therefore, sarcopenia was observed almost half of patients with liver cirrhosis, and negatively influenced the mortality and prognosis of liver disease [3,9]. Recent evidence of the interaction between osteoporosis and sarcopenia has led to the concept of osteosarcopenia, describing the concomitant development of sarcopenia and osteoporosis $[10,11]$. As common musculoskeletal complications that develop with aging, sarcopenia and osteoporosis share genetic, endocrine, and mechanical 
risk factors, and are also closely connected both mechanically and metabolically [12-15]. Osteosarcopenia has a negative effect on the quality of life and the clinical outcome in the events of falls, disability, hospitalization, and fracture, thus contributing to a higher mortality, which has highlighted its importance as a global health concern [16,17]. However, despite the high prevalence and clinical significance of osteoporosis and sarcopenia in patients with liver disease, attention and management strategies for these musculoskeletal disorders are frequently overlooked in clinical practice for patients with liver disease. Additionally, current understanding of molecular mechanism of osteosarcopenia in terms of bone and muscle crosstalk in patients with chronic liver disease is limited. Therefore, in this review, we describe what is currently known about the molecular mechanisms of osteoporosis, sarcopenia, and osteosarcopenia in chronic liver disease, to provide a comprehensive understanding of how these musculoskeletal disorders accompany the pathogenesis of liver disease and to generate interests in clinical implications of these musculoskeletal disorders in liver disease, which would be lead to promoting the clinical application of existing potential treatments, and further development of effective molecular targeted therapies for these musculoskeletal disorders in patients with liver disease.

\section{Osteoporosis in Chronic Liver Disease}

\subsection{Prevalence and Clinical Outcomes of Osteoporosis in Chronic Liver Disease}

A number of studies on osteoporosis in chronic liver disease have focused on cholestatic liver disease, including primary biliary cholangitis (PBC), primary sclerosing cholangitis (PSC), and end-stage liver cirrhosis [18]. The prevalence of osteoporosis is reported to be $20-32 \%$ in PBC and 15\% in PSC, with the severity of liver disease being a risk factor for in PBC patients [19-21]. About 10-20\% patients with $P B C$ experienced facture, and the risk of fracture in this patient group was 2-fold higher than in the general population [22,23]. Patient with non-cirrhotic chronic hepatitis B or C exhibited lower bone mineral density (BMD) and developed osteoporosis with a prevalence of 10-30\% [24-29]. Hansen et al. reported that fracture risk was higher in HCV-exposed patients [29]. In those with liver cirrhosis, the prevalence of osteoporosis was $12-28 \%$, with advanced-stage cirrhosis and alcohol-associated liver cirrhosis being significantly associated with osteoporosis [30-33]. Interestingly, liver transplantation improved BMD, especially in patients receiving less glucocorticoid treatment, without cholestasis, and exhibiting an elevation of vitamin $\mathrm{D}$ and parathyroid hormones 4-6 months after liver transplantation [34,35]. With regard to non-cholestatic liver disease, a retrospective study reported that osteoporotic fractures were 2.5-fold more common in patients with non-alcoholic fatty liver disease (NAFLD), and low BMD was more prominent in those with higher disease activity, such as in cases with non-alcoholic steatohepatitis (NASH), significant fibrosis, and a high fatty liver index [36-39]. As alcohol consumption is an independent risk factor for osteoporosis, patients with considerable alcohol consumption developed osteoporosis without liver cirrhosis [40]. About $30 \%$ and $36 \%$ of alcoholic patients showed osteoporosis and vertebral fracture upon radiologic examination, respectively [41]. Importantly, abstinence increased BMD and bone formation marker osteocalcin levels in alcoholics [42]. Osteoporosis was observed in $25-34 \%$ of patients with hereditary hemochromatosis, independent of cirrhosis or hypogonadism [43-45]. The prevalence of osteopenia and osteoporosis was $9 \%$ and $50 \%$, respectively, in patients with Wilson's disease, which was significantly higher than in the healthy population [46]. In addition, Quemeneur et al. reported that half of patients with Wilson's disease suffered peripheral fractures (Table 1) [47]. 
Table 1. Representative clinical studies for osteoporosis in chronic liver disease.

\begin{tabular}{|c|c|c|c|c|c|}
\hline \multicolumn{6}{|c|}{ Studies on Patients with Primary Biliary Cholangitis (PBC) or Primary Sclerosing Cholangitis (PSC) } \\
\hline Author, Year & Study Aim & Study Design & Study Population & $\begin{array}{l}\text { Method to } \\
\text { Diagnosis } \\
\text { Osteoporosis }\end{array}$ & Outcome \\
\hline Menon et al., 2001 [19] & $\begin{array}{l}\text { To evaluate the prevalence and risk } \\
\text { factor of bone disease in patients } \\
\text { with PBC and to determine the rate } \\
\text { of bone loss over time. }\end{array}$ & Retrospective study & 176 patients with $\mathrm{PBC}$ & DEXA & $\begin{array}{l}\text { The prevalence of osteoporosis is } 20 \% \text { in patients with } \\
\text { PBC. Age (OR 1.2 (1.1-1.2)), BMI (OR 0.8 (0.7-0.9)), } \\
\text { advanced stage (3 or 4) (OR 6.3 (1.8-21.6)), and } \\
\text { history of fractures (OR } 4.1(1.0-16.8)) \text { were } \\
\text { independent indicators of osteoporosis. Serum } \\
\text { bilirubin level was independently associated with the } \\
\text { rate of bone loss over time. }\end{array}$ \\
\hline $\begin{array}{l}\text { Guanabens et al., } 2005 \\
\text { [20] }\end{array}$ & $\begin{array}{l}\text { To find out the prevalence and risk } \\
\text { factors for osteoporosis in women } \\
\text { with PBC }\end{array}$ & $\begin{array}{l}\text { Cross-sectional } \\
\text { study }\end{array}$ & $\begin{array}{l}142 \text { women } \\
\text { with PBC and } 1305 \\
\text { age-matched control } \\
\text { subjects }\end{array}$ & DEXA & $\begin{array}{l}\text { Prevalence of osteoporosis was higher in PBC ( } 32.4 \%) \\
\text { than in normal women }(11.1 \%) \text {. Older age, higher } \\
\text { Mayo risk score, lower BMI and advanced histological } \\
\text { stage were independent risk factors for osteoporosis. }\end{array}$ \\
\hline $\begin{array}{l}\text { Solaymani-Dodaran } \\
\text { et al., } 2006 \text { [22] }\end{array}$ & $\begin{array}{l}\text { To quantify the excess fracture risk } \\
\text { in people with PBC }\end{array}$ & $\begin{array}{l}\text { Retrospective cohort } \\
\text { study }\end{array}$ & $\begin{array}{l}930 \text { patients with } \mathrm{PBC} \\
\text { and } 9202 \text { age- and } \\
\text { sex-matched control } \\
\text { subjects. }\end{array}$ & NA & $\begin{array}{l}\text { There were approximately 2-fold relative increases in } \\
\text { the risk of any fracture (HR 2.03 (1.70-2.44)), hip } \\
\text { fracture (HR } 2.14(1.40-3.28)) \text {, and ulna/radius } \\
\text { fracture (HR 1.96 (1.42-2.71)) for the PBC cohort } \\
\text { compared with the general population. }\end{array}$ \\
\hline $\begin{array}{l}\text { Guanabens et al., } 2010 \\
\text { [23] }\end{array}$ & $\begin{array}{l}\text { To assess the prevalence and risk } \\
\text { factors for fractures and the } \\
\text { fracture threshold in women } \\
\text { with PBC }\end{array}$ & Prospective study & $\begin{array}{l}185 \text { women } \\
\text { with PBC }\end{array}$ & DEXA & $\begin{array}{c}\text { The prevalences of vertebral, non-vertebral, and } \\
\text { overall fractures were } 11.2 \%, 12.2 \% \text {, and } 20.8 \% \text {, } \\
\text { respectively. Vertebral fractures, are associated with } \\
\text { osteoporosis (OR } 8.48(2.67-26.95) \text { ). Osteoporosis and } \\
\text { osteopenia are associated with the severity of } \\
\text { liver damage. }\end{array}$ \\
\hline Angulo et al., 2011 [21] & $\begin{array}{l}\text { To identify prevalence and rate of } \\
\text { progression of bone disease in } \\
\text { patients with PSC and to identify } \\
\text { predictors of bone disease } \\
\text { and progression. }\end{array}$ & $\begin{array}{l}\text { Retrospective } \\
\text { longitudinal cohort } \\
\text { study }\end{array}$ & 237 patients with PSC & DEXA & $\begin{array}{c}\text { Osteoporosis was found in } 15 \% \text { of patients (RR } 23.8 \\
\text { (4.6-122.8)). Old age (OR 7.8 (3.3-18.3), BMI (OR } 4.9 \\
\text { (1.9-12.6), and long duration of inflammatory bowel } \\
\text { disease (OR 3.6 (1.5-8.4)) correlated with the presence } \\
\text { of osteoporosis. }\end{array}$ \\
\hline
\end{tabular}


Table 1. Cont

\section{Studies on Patients with Viral Hepatitis}

\section{Author, Year}

Study Aim
Study Design

Study Population

\section{Method to \\ Diagnosis \\ Osteoporosis}

Outcome

43 patients with $\mathrm{HCV}$

To evaluate BMD and bone

Schiefke et al., 2005 [28] turnover markers in patients with

Cross-sectional $\quad(n=30)$ or $\operatorname{HBV}(n=13)$

infection without
study liver cirrhosis.

DEXA

non-cirrhotic $\mathrm{CHB}$ or $\mathrm{CHC}$

To identify the prevalence of osteoporotic vertebral fractures and low BMD measurements in men with non-cirrhotic $\mathrm{CHC}$. study
Cross-sectional
60 non-cirrhotic $\mathrm{CHC}$ patients and 59 healthy controls
12,013 HCV-exposed

patients from the

Danish HCV cohort,

and 60,065 general population
Hansen et al., 2014 [29] (HCV-exposed) patients and the general population, and between

patients with cleared and $\mathrm{CHC}$ infection.
Retrospective cohort study
Association between BMD,

systemic inflammation, and markers of bone turnover in $\mathrm{CHC}$ without cirrhosis
Cross-sectional study

60 non-cirrhotic $\mathrm{CHC}$
patients
DEXA

DEXA

20

Osteoporosis is observed in 32\% of non-cirrhotic $\mathrm{CHB}$ or $\mathrm{CHC}$ patients. Altered bone metabolism with increased bone-specific ALP and iPTH already occurred in advanced liver fibrosis without cirrhosis.

Non-cirrhotic untreated $\mathrm{CHC}$ patients have lower BMD at the femur as compared to healthy men in spite of the absence of significant bone and mineral abnormalities.

HCV-exposed patients had increased risk of all fracture types (adjusted incidence rate ratio (aIRR) 2.13-2.18) whereas overall risk of fracture did not differ between patients with chronic vs. cleared HCV-infection.

Low BMD was observed in $42 \%$ (30\% had osteopenia,

$12 \%$ had osteoporosis) of non-cirrhotic CHC patients, but not associated with systemic inflammatory markers. Patients with low BMD had higher serum phosphorus and pro-peptide of type 1 collagen.

The prevalence of osteoporosis in either of lumbar spine, total hip or the femur neck was significantly higher in the CHB patients group $(12.8 \%, 11.5 \%$,
$148 \mathrm{CHB}$ patients and

148 age- and

Huang et al., 2017 [26] To assess BMD and prevalence of

Case-control study gender-matched healthy controls
DEXA

$12.2 \%)$ compared with the healthy control $(4.7 \%, 4.1 \%$,

$4.7 \%)$. CHB infection was associated with low BMD and increased the risk of osteoporosis.
There is no significant increase in the incidence of osteopenia/osteoporosis for patients with $\mathrm{CHB}$ treated with TDF (HR 0.74 (0.34-1.59)) or ETV (HR $0.98(0.51-1.90))$ during a median follow-up of about 4 to 5 years. 
Table 1. Cont.

Studies on Patients with Liver Cirrhosis (LC)

\begin{tabular}{|c|c|c|c|c|c|}
\hline \multicolumn{6}{|c|}{ Studies on Patients with Liver Cirrhosis (LC) } \\
\hline Author, Year & Study Aim & Study Design & Study Population & $\begin{array}{l}\text { Method to } \\
\text { Diagnosis } \\
\text { Osteoporosis }\end{array}$ & Outcome \\
\hline Monegal et al. 1997 [33] & $\begin{array}{l}\text { To find out the prevalence and risk } \\
\text { factor of bone disease in patients } \\
\text { with end-stage liver disease } \\
\text { waiting for OLT. }\end{array}$ & Prospective study & 58 cirrhotic patients & DEXA & $\begin{array}{l}43 \% \text { patients had osteoporosis and vitamin D de- } \\
\text { ficiency, reduced PTH levels, and hypogonadism are } \\
\text { observed in cirrhotic patients. Alcoholic and Child- } \\
\text { Pugh C patients showed the lowest femoral BMD. }\end{array}$ \\
\hline $\begin{array}{l}\text { Sokhi et al., } 2004 \\
\text { [31] }\end{array}$ & $\begin{array}{l}\text { To assess the BMD in different } \\
\text { subgroups among pretransplant } \\
\text { cirrhotic patients. }\end{array}$ & Retrospective study & 104 cirrhotic patients & DPA & $\begin{array}{l}\text { The overall prevalence of osteopenia and osteoporosis } \\
\text { were } 34.6 \% \text { and } 11.5 \% \text {, respectively, being } \\
\text { significantly higher in females than in males. BMD is } \\
\text { significantly lower in those with CTP class C than } \\
\text { those with CTB class B in both males and females. }\end{array}$ \\
\hline $\begin{array}{l}\text { Goubraim et al., } 2013 \\
\text { [30] }\end{array}$ & $\begin{array}{l}\text { To evaluate prevalence and risk } \\
\text { factors for metabolic bone disease } \\
\text { in patients with viral cirrhosis }\end{array}$ & Prospective study & 46 cirrhotic patients & DEXA. & $\begin{array}{l}\text { Osteopenia and osteoporosis is observed in } 52.2 \% \text { and } \\
28.2 \% \text { patients, respectively. There was no } \\
\text { independent factor associated with bone disorders } \\
\text { although bone disorders were significantly more } \\
\text { frequent in old patients with low BMI, long duration } \\
\text { of liver disease, and low vitamin D level. }\end{array}$ \\
\hline Zheng et al., 2018 [32] & $\begin{array}{l}\text { To evaluate osteoporosis or } \\
\text { osteopenia in patients with } \\
\text { cirrhosis }\end{array}$ & Retrospective study & $\begin{array}{l}217 \text { LC patients and } 229 \\
\text { subjects without liver } \\
\text { diseases }\end{array}$ & DEXA & $\begin{array}{c}\text { Osteoporosis was found in } 20.3 \% \text { and older age (OR } \\
\text { 1.78), lower BMI (OR 0.63), greater fibroscan score } \\
\text { (OR 1.15), and alcoholic liver cirrhosis (OR 3.42) were } \\
\text { independently associated with osteoporosis in } \\
\text { cirrhotic patients. }\end{array}$ \\
\hline \multicolumn{6}{|c|}{ Studies on Patients Who Underwent Liver Transplantation } \\
\hline Author, Year & Study Aim & Study Design & Study Population & $\begin{array}{l}\text { Method to } \\
\text { Diagnosis } \\
\text { Osteoporosis }\end{array}$ & Outcome \\
\hline Monegal et al., 2001 [34] & $\begin{array}{l}\text { To determine the incidence and } \\
\text { risk factors of skeletal fractures and } \\
\text { to analyze the long-term evolution } \\
\text { of bone mass, bone turnover and } \\
\text { hormonal status after LT }\end{array}$ & Prospective study & 45 patients following $\mathrm{LT}$ & DEXA & $\begin{array}{c}\text { Fifteen patients ( } 33 \%) \text { developed fractures after liver } \\
\text { transplantation, and pre- transplant risk factors for } \\
\text { fractures were age and low bone mass (OR } 5.69 \\
(1.32-24.53) \text { ). Bone mass decreased during the first } \\
6 \text { months and after then bone formation parameters } \\
\text { is increased. }\end{array}$ \\
\hline
\end{tabular}


Table 1. Cont

\section{Studies on Patients Who Underwent Liver Transplantation}

Author, Year

Study Aim

Study Design

Study Population

Method to

Diagnosis

Osteoporosis

To identify the prevalence and predictive factors for low bone Guichelaar et al., 2006 mass before OLT, Posttransplant [35]

bone loss, and bone gain at the

lumbar spine with long-term follow-up after OLT
Prospective cohort 360 patients with study end-stage PBC and PSC
DPA \& DEXA

\section{Outcome}

Most patients (77\%) with advanced PBC and PSC have osteopenic bone disease, and risk factors for hepatic osteopenia are low BMI, older age postmenopausal status, the presence of muscle wasting, high ALP, and low serum albumin. After OLT, aggressive bone loss occurs during the first

4 months, with risk factor of younger age, PSC, higher pretransplant BMD, no IBD, shorter duration of disease, current smoking and ongoing cholestasis at 4 months. After the first 4 postoperative months, bone gain occurs during the first 2 years with favoring factors for improvement of lower baseline and/or 4-month BMD, premenopausal status for females, lesser glucocorticoids, no ongoing cholestasis, and higher levels of vitamin D and parathyroid function.

Studies on Patients with Non-Alcoholic Fatty Liver Disease (NAFLD)

\begin{tabular}{|c|c|c|c|c|c|}
\hline Author, Year & Study Aim & Study Design & Study Population & $\begin{array}{l}\text { Method to } \\
\text { Diagnosis } \\
\text { Osteoporosis }\end{array}$ & Outcome \\
\hline Li et al., 2012 [36] & $\begin{array}{c}\text { Association between NAFLD and } \\
\text { osteoporotic fracture }\end{array}$ & $\begin{array}{l}\text { Cross-sectional } \\
\text { study }\end{array}$ & $\begin{array}{l}7797 \text { Chinese adults } \\
\text { (including } 2352 \text { patients } \\
\text { with NAFLD) }\end{array}$ & NA & $\begin{array}{l}\text { The prevalence of osteoporotic fractures was } \\
\text { significantly higher in men with NAFLD ( } 3.6 \mathrm{vs.} \\
1.7 \%) \text {, and the presence of NAFLD was significantly } \\
\text { associated with osteoporotic fracture among men. } \\
\text { (OR } 2.53(1.26-5.07))\end{array}$ \\
\hline Kim et al., 2017 [38] & $\begin{array}{l}\text { Association between liver fibrosis } \\
\text { and BMD in patients with NAFLD }\end{array}$ & $\begin{array}{l}\text { Retrospective } \\
\text { cross-sectional } \\
\text { study }\end{array}$ & $\begin{array}{l}231 \text { subjects (including } \\
129 \text { patients with } \\
\text { NAFLD) }\end{array}$ & DEXA & $\begin{array}{l}\text { Significant liver fibrosis was independently } \\
\text { associated with overall osteopenia and osteoporosis } \\
\text { in subjects with NAFLD. (OR } 4.10(1.02-16.45)) \text {. }\end{array}$ \\
\hline
\end{tabular}


Table 1. Cont.

\begin{tabular}{|c|c|c|c|c|c|}
\hline \multicolumn{6}{|c|}{ Studies on Patients with Non-Alcoholic Fatty Liver Disease (NAFLD) } \\
\hline Author, Year & Study Aim & Study Design & Study Population & $\begin{array}{c}\text { Method to } \\
\text { Diagnosis } \\
\text { Osteoporosis }\end{array}$ & Outcome \\
\hline Ahn et al., 2018 [39] & $\begin{array}{l}\text { Association between fatty liver } \\
\text { index (scoring model for NAFLD) } \\
\text { and BMD }\end{array}$ & $\begin{array}{l}\text { Population-based, } \\
\text { cross-sectional } \\
\text { study }\end{array}$ & 4264 adults & DEXA & $\begin{array}{c}\text { Fatty liver index was negatively correlated with total } \\
\text { hip }(p=0.004), \text { femoral neck }(p<0.001), \text { and whole } \\
\text { body BMD ( } p=0.01) \text { in men independent of } \\
\text { insulin resistance. }\end{array}$ \\
\hline \multicolumn{6}{|c|}{ Studies on Alcoholics } \\
\hline Author, Year & Study Aim & Study Design & Study Population & $\begin{array}{c}\text { Method to } \\
\text { Diagnosis } \\
\text { Osteoporosis }\end{array}$ & Outcome \\
\hline Peris et al., 1994 [42] & $\begin{array}{l}\text { To evaluate the effect of abstinence } \\
\text { on bone mass and bone mineral } \\
\text { metabolism in chronic alcoholics. }\end{array}$ & $\begin{array}{l}2 \text { year longitudinal } \\
\text { follow-up study }\end{array}$ & $\begin{array}{l}30 \text { chronic alcoholic } \\
\text { males }\end{array}$ & DPA & $\begin{array}{c}\text { After } 2 \text { years of abstinence, Lumbar and femoral neck } \\
\text { BMD increased in alcoholics and Baseline low } \\
\text { osteocalcin increased after } 1 \text { year and } 2 \text { years of } \\
\text { abstinence. }\end{array}$ \\
\hline Peris et al., 1995 [41] & $\begin{array}{l}\text { Association between vertebral } \\
\text { facture and osteopenia in chronic } \\
\text { alcoholics patients. }\end{array}$ & $\begin{array}{l}\text { Cross-sectional } \\
\text { study }\end{array}$ & $\begin{array}{l}76 \text { chronic alcoholics } \\
\text { and } 62 \text { age matched } \\
\text { healthy males. }\end{array}$ & DPA & $\begin{array}{l}\text { Chronic alcoholics frequently have traumas }(68 \%) \\
\text { and vertebral fractures }(36 \%) \text { in spite of having a } \\
\text { lumbar BMD above the fracture threshold. }\end{array}$ \\
\hline Malik et al., 2009 [40] & $\begin{array}{l}\text { To evaluate BMD according to } \\
\text { alcohol consumption and sex. }\end{array}$ & $\begin{array}{l}\text { Cross-sectional } \\
\text { study }\end{array}$ & $\begin{array}{l}57 \text { noncirrhotic } \\
\text { alcoholic patients }\end{array}$ & DEXA & $\begin{array}{c}24.3 \% \text { of men and } 5 \% \text { of women had low BMD and } \\
75.7 \% \text { of the men and } 90 \% \text { of the women had vitamin } \\
\text { D insufficiency or deficiency. }\end{array}$ \\
\hline \multicolumn{6}{|c|}{ Studies on Patients with Genetic Hemochromatosis (GH) or Wilson Disease (WD) } \\
\hline Author, Year & Study Aim & Study Design & Study Population & $\begin{array}{l}\text { Method to } \\
\text { Diagnosis } \\
\text { Osteoporosis }\end{array}$ & Outcome \\
\hline $\begin{array}{c}\text { Sinigaglia et al., } 1997 \\
{[43]}\end{array}$ & $\begin{array}{l}\text { To evaluate the prevalence and risk } \\
\text { factor of osteoporosis in } \mathrm{GH}\end{array}$ & $\begin{array}{l}\text { Cross sectional } \\
\text { study }\end{array}$ & $\begin{array}{c}32 \text { patients with } \\
\text { histologically proven } \\
\text { GH }\end{array}$ & DEXA & $\begin{array}{l}\text { Osteoporosis is observed in } 28 \% \text { and osteoporosis is } \\
\text { highly associated with degree of iron overload (OR } \\
\qquad 3.23(1.09-9.58))\end{array}$ \\
\hline $\begin{array}{c}\text { Guggenbuhl et al., } 2005 \\
{[44]}\end{array}$ & $\begin{array}{l}\text { To assess BMD and bone } \\
\text { remodeling in patients with GH }\end{array}$ & Retrospective study & $\begin{array}{l}38 \text { men with } \\
\text { HFE-related GH }\end{array}$ & DEXA & $\begin{array}{c}\text { Osteopenia was observed in } 78.9 \% \text { of patients and } \\
\text { osteoporosis in } 34.2 \% \text { that cannot solely be explained } \\
\text { by hypogonadism or cirrhosis }\end{array}$ \\
\hline
\end{tabular}


Table 1. Cont.

Studies on Patients with Genetic Hemochromatosis (GH) or Wilson Disease (WD)

\begin{tabular}{|c|c|c|c|c|c|}
\hline Author, Year & Study Aim & Study Design & Study Population & $\begin{array}{l}\text { Method to } \\
\text { Diagnosis } \\
\text { Osteoporosis }\end{array}$ & Outcome \\
\hline $\begin{array}{c}\text { Quemeneur et al., } 2014 \\
\text { [47] }\end{array}$ & $\begin{array}{l}\text { To assess the prevalent fractures, } \\
\text { BMD and related risk factors in } \\
\text { patients with WD. }\end{array}$ & $\begin{array}{l}\text { Prospective } \\
\text { cross-sectional } \\
\text { study }\end{array}$ & 85 patients with WD & DEXA & $\begin{array}{c}\text { Prevalent peripheral fractures were presented in } 51 \% \text {, } \\
\text { and vertebral fracture in } 8 \% \text { patients. Patients with } \\
\text { severe neurological involvement, low BMI, old age } \\
\text { are at risk factors for vertebral fractures }\end{array}$ \\
\hline Weiss et al., 2015 [46] & $\begin{array}{l}\text { Comparison of BMD between adult } \\
\text { WD and healthy control population }\end{array}$ & $\begin{array}{l}\text { Cross sectional } \\
\text { study }\end{array}$ & $\begin{array}{l}148 \text { adult WD patients } \\
\text { and } 345 \text { age and gender } \\
\text { matched control } \\
\text { subjects }\end{array}$ & DEXA & $\begin{array}{l}\text { Osteoporosis ( } 8.8 \% \text { vs. } 4.1 \%) \text { and osteopenia }(50.0 \% \\
\text { vs. } 41.2 \%) \text { is significantly more prevalent in patient } \\
\text { with WD than healthy population. There was no } \\
\text { significant correlation between BMD and any of the } \\
\text { WD disease parameters (e.g., the severity of liver } \\
\text { disease), lab results, type of treatment or known } \\
\text { osteoporosis risk factors. }\end{array}$ \\
\hline
\end{tabular}

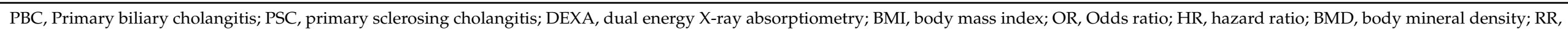

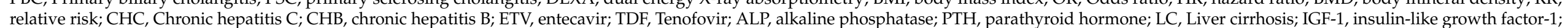

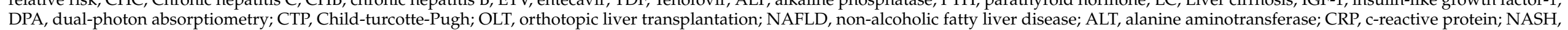
non-alcoholic steatohepatits; GH, genetic hemochromatosis; WD, Wilson disease; HHC, Hereditary hemochromatosis. 


\subsection{Molecular Mechanism of Osteoporosis in Chronic Liver Disease}

The pathophysiology of chronic liver disease-associated osteoporosis is complex. Increased bone resorption is an important pathological characteristic of osteoporosis, especially in patients with end-stage cholestatic liver disease, viral hepatitis, and NAFLD. Suggested molecular mechanisms underlying bone resorption in chronic liver disease include the receptor activator of nuclear factor kappa (RANK)-RANK ligand (RANKL)osteoprotegerin (OPG) system, upregulation of proinflammatory cytokines, such as interleukin-1 (IL-1), IL-6, and tumor necrosis factor alpha (TNF- $\alpha$ ), as well as low levels of testosterone $[1,2,48,49]$. Bone remodeling is tightly regulated by osteocytes and osteoblasts through different cytokines and hormones modulating the activation, resorption, reversal, formation, and termination phase [50]. Various types of signals are involved, including mechanical strain, bone damage, as well as hormone-induced bone remodeling via macrophage colony-stimulating factor (M-CSF), RANKL, and OPG secreted by osteoblasts. RANKL and OPG are members of the TNF superfamily and are crucial for the regulation of bone resorption [51]. RANKL, through its receptor RANK, activates osteoclast formation, activation, and survival, while OPG, which is another receptor for RANKL, restrains osteoclastogenesis and inhibits bone loss by binding RANKL to prevent the RANK-RANKL cascade [51]. RANKL is a type II transmembrane protein with a C-terminal extracellular domain. This ectodomain cleaved is cleaved by matrix metalloproteinases to yield soluble RANKL (sRANKL) in the extracellular environment and both membrane-bound and sRANKL bind to RANK [52]. In chronic liver disease, an imbalance between RANKL and OPG leads to high sRANKL levels, which increases bone turnover. Thus, the ratio of OPG/sRANKL might indicate a homeostatic response for bone mass preservation [53]. Moschen et al. reported that sRANKL levels were higher in patients with liver disease than those in controls, except those in the cirrhotic subgroup, while OPG levels were found to be proportional to the severity of liver disease and highest in the cirrhotic subgroup with osteoporosis and osteopenia, resulting in a greater OPG/sRNAKL ratio in the cirrhotic subgroup with osteoporosis and osteopenia than in cirrhotic patients with normal BMD. These results suggested that high sRNAKL levels corresponded to increased bone turnover in patients with liver disease, and that OPG was also increased to compensate for negative bone turnover. Therefore, the high OPG/sRANKL ratio could be explained a response to maintain bone homeostasis in these patients [54]. In addition, RANKL/OPG gene expression, indicative of osteoblast-related osteoclastogenesis, was increased in the serum of jaundice patients [55].

In a chronic inflammation state, proinflammatory cytokines, especially IL-6, IL-1, and TNF- $\alpha$, contribute to osteoclast activation and subsequent bone resorption [56]. IL-6 and IL-1 directly modulated osteoclastogenesis by enhancing osteoclast function [57]. They was also shown to indirectly promote osteoclast activity by facilitating RANKL production in osteoblasts [56-59]. Experimental studies revealed that IL-6 was associated with disrupted osteogenesis of bone marrow stem cells in osteoporosis models, and suppression of the IL-6 receptor prevented osteoclast-mediated bone resorption [60,61]. As IL-6 increases during liver injury to stimulate liver regeneration, upregulated IL- 6 could affect bone remodeling in various types of liver disease [62,63]. Additionally, ethanol seems to activate osteoclasts through the induction of IL- 6 and TNF- $\alpha[64,65]$. Another potent inflammatory cytokine, TNF- $\alpha$, is also involved in inflammatory bone resorption by stimulating RANKL expression in osteoblasts and tissue stromal cells, in turn promoting osteoclast differentiation and activity [66]. In particular, TNF- $\alpha$ enhanced CSF-1 receptor gene expression during the initial stage of osteoclastogenesis and subsequently stimulated osteoblast precursors, which resulted in increased osteoclast formation independent of the RANKL pathway [67]. These proinflammatory cytokines had effects on osteoporosis in viral hepatitis and NASH. Gonzalez-Calvin et al. showed that serum soluble TNF receptor p55 levels were significantly higher in patients with viral cirrhosis with osteoporosis than those without osteoporosis and positively associated with bone resorption [68]. In addition, 
since obesity is considered a chronic inflammatory state, these proinflammatory cytokines contribute to osteoporosis in NAFLD [69]. Indeed, low BMD is significantly associated with NASH presenting elevated alanine aminotransferase (ALT) and C-reactive protein (CRP) than in simple steatosis [37]. Another study showed that TNF- $\alpha$ levels are elevated in pediatric NASH [70]. Furthermore, Kim et al. reported that liver fibrosis in NAFLD is significantly correlated with low BMD, suggesting an association between aggravation of hepatic inflammation, fibrosis, and bone loss in NAFLD patients [38]. These proinflammatory cytokines have also been proposed as involved in dysbiosis-induced osteoporosis associated with chronic liver disease. Altered short-chain fatty acid (SCFA) levels and increased gut permeability ("leaky-gut syndrome") may affect bone remodeling by regulating inflammation and immune system [2]. In addition, impaired liver function and cholestasis result in decreased 25-hydroxylation and intestinal absorption of vitamin D. Vitamin D deficiency is associated with osteoporosis in patients with liver cirrhosis [30,33]. Calcium and vitamin D deficiencies in patients with cholestatic liver disease caused secondary hyperparathyroidism, subsequently enhancing bone resorption [71]. Vitamin K is known to be involved in osteoblast apoptosis inhibition and osteoclast differentiation [72-74]. Therefore, decreased vitamin $\mathrm{K}$ levels were suggested to affect bone metabolism in chronic liver disease. Vitamin K deficiency reduced bone matrix proteins such as osteocalcin and osteonectin in patients with $\mathrm{PBC}[75,76]$.

Bone formation is also compromised in chronic liver disease as a result of toxic materials, sclerostin, and decreased anabolic hormones, which contribute to osteoporosis in patients with $\mathrm{PBC}$, advanced stage liver cirrhosis, hereditary hemochromatosis, and Wilson disease $[1,2,48]$. Direct or indirect toxic compounds such as bilirubin, alcohol, iron, and copper accumulate in specific liver diseases, which can impair bone formation by inhibiting osteoblast proliferation and differentiation as well as bone mineralization by osteoblasts $[45,55]$. Unconjugated bilirubin decreased the survival of osteoblast, and osteoblast differentiation was significantly reduced only in jaundiced patients, except in patients with normal bilirubin levels, whereas ursodeoxycholic acid compensated for the negative effect of cholestatsis on osteoblast survival, proliferation and mineralization $[55,77]$. Previous studies reported that the severity of liver disease including cholestasis is significantly associated with osteoporosis in patients with PBC $[19,20,23]$. In hereditary hemochromatosis, lumbar spine BMD is significantly decreased in parallel to an increase of iron and alkaline phosphatase (ALP) levels [45]. In addition, bone synthesis is lower in alcoholic patients with low levels of osteocalcin, which is secreted from osteoblasts, and plays a role in calcium homeostasis, bone matrix mineralization, and osteoblastic proliferation [53]. Under physiological conditions, after bone resorption, mesenchymal stem cells and early osteoblast progenitors differentiate into osteoblasts through Wnt, bone morphogenetic protein (BMP), and fibroblast growth factor (FGF) signaling, leading to bone formation $[2,78]$. As a regulator of bone formation, sclerostin is produced in osteocytes and hinders osteoblast differentiation and proliferation, subsequently restricting bone formation by antagonizing Wnt signaling via binding to low-density lipoprotein receptor-related proteins (LRP) 5/6 transmembrane receptors [79,80]. As a result of sclerostin expression, the Wnt receptor is blocked and glycogen synthase kinase 3 phosphorylates $\beta$-catenin, which is involved in ubiquitination and degradation through the proteasome pathway [81]. Guanabens et al. proposed sclerostin as a crucial regulator of the Wnt/ $\beta$-catenin pathway in relation to bone formation in patients with PBC [82]. A cross-sectional study revealed that sclerostin levels were significantly increased in patients with advanced cirrhosis when compared to those with early cirrhosis or healthy controls [83].

Insulin-like growth factor (IGF-1), which is secreted from hepatocytes by growth hormone $(\mathrm{GH})$ has an anabolic effect on bone growth by suppressing osteoblast apoptosis and enhancing osteoblastogenesis through stabilization of the Wnt/ $\beta$-catenin pathway [84,85]. In addition, IGF-1 reduced bone resorption through the OPG and RANKL system [86]. In end-stage liver disease, hepatocellular dysfunction and reduced GH receptors lead to low serum IGF-1 levels, subsequently causing osteoporosis [87]. Insulin, an important 
hormone associated with NAFLD, also affects bone remodeling by activating collagen synthesis and stimulating osteoblast proliferation and differentiation [88]. In addition, hypogonadism, which results from hyperestrogenism of portal hypertension in males and suppression of the hypothalamic-pituitary-gonadal axis in females, is frequently observed in hemochromatosis, liver cirrhosis, and alcoholics liver disease $[1,89]$. Since testosterone directly modulates osteoblasts and osteocytes via the androgen receptor to stimulate trabecular bone formation and prevent its loss, low testosterone level owing to hypogonadism in male enhances osteoclast function and induces bone turnover $[53,90]$. Though estrogen levels are increased in patient with liver cirrhosis due to increased peripheral conversion of androgen to estrogen, altered estrogen metabolism in liver cirrhosis contributes to a decrease in degradation of estrogen metabolites [91]. Because the bone protective effect of these estrogens is weak, it is not enough to overcome post-menopausal osteoporosis in women and liver-disease related osteoporosis in men [92,93].

\section{Sarcopenia in Chronic Liver Disease}

\subsection{Definition of Sarcopenia}

Sarcopenia, a condition characterized by the loss of skeletal muscle mass and strength, has been explored as a prognostic predictor for various diseases [94]. However, consensus criteria for the diagnosis of sarcopenia have not yet been established, and different definitions have been proposed by several groups $[95,96]$. The European Working Group on Sarcopenia in Older People (EWGSOP) first proposed the definition of sarcopenia in 2010, with muscle mass being a cardinal requirement for sarcopenia diagnosis [97]. The working group categorized sarcopenia into two categories. Primary sarcopenia referred to agerelated muscle mass deterioration, while secondary sarcopenia was defined as caused by factors other than aging, such as inflammatory processes, disease-related disabilities, and inadequate energy or protein intake. Given the growing body of scientific data on sarcopenia, the EWGSOP recently updated diagnostic criteria so that muscle strength is the principal determinant for diagnosis with strict cut-off values (hand grip strength $<27 \mathrm{~kg}$ for men and $<16 \mathrm{~kg}$ for women) due to its significant correlation with clinical outcomes when compared to muscle mass [95]. According to the revised criteria, sarcopenia is defined as low muscle strength in parallel to low muscle mass or decreased muscle function. In contrast, the Asian Working Group for Sarcopenia (AWGS) regarded low muscle mass as the cardinal criterion for the diagnosis of sarcopenia. Therefore, AWGS defined sarcopenia as low muscle mass with low muscle strength or low physical performance [96]. Further, both EWGSOP2 and AWGS recognize entirely impaired muscle mass, muscle strength, and muscle function as diagnostic criteria for severe sarcopenia $[95,96]$. On the other hand, Clark et al. proposed in 2008 the concept of dynapenia, a state of age-associated decline in muscle strength which focused on other physiologic factors except for muscle mass loss in 2008 [98]. Therefore, dynapenia is similar to the revised EWGSOP definition of sarcoepnia in that decrease of skeletal muscle mass was not always necessary for the diagnosis of dynapenia, but sarcopenia is recognized to develop earlier in life, unlike dynapenia.

\subsection{Prevalence and Clinical Outcomes of Sarcopenia in Chronic Liver Disease}

Sarcopenia results from the accelerated loss of muscle mass and function, which in turn contributes to adverse clinical outcomes including fracture, frailty, and mortality. Although the prevalence of sarcopenia depends on the definition used, which is based on, for example, muscle mass cutoff points as well as other factors, the condition has been rigorously studied in the context of various chronic liver diseases (Table 2) [94]. With regard to non-alcoholic liver disease, previous studies reported a significant relationship between sarcopenia, sarcopenic obesity, and NAFLD, with this association being later described as independent of obesity and insulin resistance [99-103]. 
Table 2. Representative clinical studies for sarcopenia in chronic liver disease.

\begin{tabular}{|c|c|c|c|c|c|}
\hline \multicolumn{6}{|c|}{ Studies on Patients with Non-Alcoholic Fatty Liver Disease (NAFLD) } \\
\hline Author, Year & Study Aim & Study Design & Study Population & $\begin{array}{l}\text { Method to } \\
\text { Diagnosis } \\
\text { Sarcopenia }\end{array}$ & Outcome \\
\hline Hong et al., 2014 [100] & $\begin{array}{l}\text { Relationship between sarcopenia } \\
\text { and NAFLD }\end{array}$ & $\begin{array}{l}\text { Cross-sectional } \\
\text { study }\end{array}$ & 452 subjects & DEXA & $\begin{array}{l}\text { Lower muscle mass increased the risk of NAFLD (OR } \\
\qquad 5.16(1.63-16.33)) .\end{array}$ \\
\hline Lee et al., 2015 [99] & $\begin{array}{l}\text { Association between sarcopenia } \\
\text { and NAFLD or NASH }\end{array}$ & $\begin{array}{l}\text { Cross-sectional } \\
\text { study }\end{array}$ & 15,132 subjects & DEXA & $\begin{array}{l}\text { There was independent association between } \\
\text { sarcopenia and NAFLD after adjusting for } \\
\text { confounding factors related to obesity or insulin } \\
\text { resistance (ORs } 1.18 \text { to } 1.22 \text { ) }\end{array}$ \\
\hline Carias et al., 2016 [101] & $\begin{array}{c}\text { Association between sarcopenic } \\
\text { obestiy and NASH in patients with } \\
\text { LC }\end{array}$ & Retrospective study & 207 patients with LC & $\begin{array}{l}\text { L3-L4 skeletal } \\
\text { muscle mass on CT } \\
\text { imaging, DEXA }\end{array}$ & $\begin{array}{l}\text { NASH is independent predictor of sarcopenia obesity } \\
\text { in patients with LC (OR } 6.03(1.44-25.26))\end{array}$ \\
\hline Koo et al., 2017 [102] & $\begin{array}{l}\text { Association between sarcopenia } \\
\text { and histological severity of NAFLD }\end{array}$ & $\begin{array}{l}\text { Prospective } \\
\text { cross-sectional } \\
\text { study }\end{array}$ & $\begin{array}{l}309 \text { patients (including } \\
240 \text { biopsy proven } \\
\text { NAFLD patients) }\end{array}$ & BIA & $\begin{array}{l}\text { Sarcopenia was significantly associated with NASH } \\
(\text { OR } 2.28(1.12-4.30) \text { ) and significant fibrosis (OR } 2.05 \\
(1.01-4.16)) \text {. }\end{array}$ \\
\hline Kim et al., 2018 [104] & $\begin{array}{l}\text { Effect of skeletal muscle mass } \\
\text { changes on NAFLD }\end{array}$ & $\begin{array}{l}\text { 7-year } \\
\text { longitudinal } \\
\text { cohort study }\end{array}$ & $\begin{array}{l}\text { 10,534 subjects without } \\
\text { baseline NAFLD and } \\
2631 \text { subjects with } \\
\text { baseline NAFLD }\end{array}$ & BIA & $\begin{array}{l}\text { Increases in relative skeletal muscle mass over time } \\
\text { may lead to benefits either in the development of } \\
\text { NAFLD (aHR } 0.44(0.38-0.51)) \text { or the resolution of } \\
\text { existing NAFLD (aHR } 2.09(1.02-4.28)) \text {. }\end{array}$ \\
\hline Gan et al., 2020 [103] & $\begin{array}{l}\text { Associations of NAFLD with low } \\
\text { muscle mass, low muscle strength, } \\
\text { sarcopenia, and sarcopenic obesity }\end{array}$ & $\begin{array}{l}\text { Cross-sectional } \\
\text { study }\end{array}$ & $\begin{array}{l}5132 \text { participants } \\
\text { (including } 1088 \text { patients } \\
\text { with NAFLD) }\end{array}$ & DEXA & $\begin{array}{c}\text { Low muscle mass (OR 2.57 (2.03-3.25)), low muscle } \\
\text { strength (OR 1.47 (1.21-1.80)), sarcopenia (OR 3.91 } \\
(2.90-5.28) \text { ), sarcopenic obesity (OR 1.42 (7.14-15.22)) } \\
\text { were positively and associated with NAFLD. }\end{array}$ \\
\hline \multicolumn{6}{|c|}{ Studies on Patients with Liver Cirrhosis (LC) } \\
\hline Author, Year & Study Aim & Study Design & Study Population & $\begin{array}{l}\text { Method to } \\
\text { Diagnosis } \\
\text { Sarcopenia }\end{array}$ & Outcome \\
\hline Tandon et al., 2012 [105] & $\begin{array}{l}\text { Prevalence of sarcopenia and } \\
\text { clinical significance of sarcopenia } \\
\text { in patients with cirrhosis listed } \\
\text { for LT }\end{array}$ & Retrospective study & $\begin{array}{l}142 \text { LC patients waiting } \\
\text { for LT }\end{array}$ & $\begin{array}{l}\text { L3 skeletal muscle } \\
\text { on CT and MRI } \\
\text { images. DEXA }\end{array}$ & $\begin{array}{l}\text { The prevalence of sarcopenia was } 41 \% \text {, and } \\
\text { sarcopenia is independent predictor of mortality (HR } \\
2.36(1.23-4.53))\end{array}$ \\
\hline
\end{tabular}


Table 2. Cont

\begin{tabular}{|c|c|c|c|c|c|}
\hline \multicolumn{6}{|c|}{ Studies on Patients with Liver Cirrhosis (LC) } \\
\hline Author, Year & Study Aim & Study Design & Study Population & $\begin{array}{l}\text { Method to } \\
\text { Diagnosis } \\
\text { Sarcopenia }\end{array}$ & Outcome \\
\hline $\begin{array}{l}\text { Montano-Loza et al., } \\
2012 \text { [106] }\end{array}$ & $\begin{array}{l}\text { Incidence of sarcopenia, association } \\
\text { between sarcopenia and mortality } \\
\text { and prognosis in LC patients }\end{array}$ & Prospective study & 112 patients with LC & $\begin{array}{l}\text { L3 skeletal muscle } \\
\text { on CT images }\end{array}$ & $\begin{array}{l}\text { The incidence of sarcopenia is } 40 \% \text {. Sarcopenia is } \\
\text { associated with mortality in patients with cirrhosis. } \\
\text { (HR 2.21) }\end{array}$ \\
\hline Merli et al., 2013 [107] & $\begin{array}{l}\text { The relationship between muscle } \\
\text { depletion and hepatic } \\
\text { encephalopathy (HE) }\end{array}$ & Prospective study & 300 patients with LC & $\begin{array}{l}\text { Mid-Arm-Muscle- } \\
\text { Circumference, } \\
\text { Triceps } \\
\text { Skinfold-Thickness, } \\
\text { Handgrip strength }\end{array}$ & $\begin{array}{l}\text { HE were significantly higher in cirrhotic patients with } \\
\text { muscle depletion or decreased muscle strength. (30\% } \\
\text { vs. } 15 \% \text {, and } 29 \% \text { vs. } 16 \% \text {, respectively) }\end{array}$ \\
\hline Kim et al., 2014 [108] & $\begin{array}{l}\text { The association between } \\
\text { sarcopenia and long term mortality } \\
\text { in LC patients with ascites }\end{array}$ & Retrospective study & 65 patients with LC & $\begin{array}{l}\text { psoas muscle } \\
\text { thickness on CT } \\
\text { images }\end{array}$ & $\begin{array}{l}\text { Sarcopenia is an independent useful predictor for } \\
\text { long-term mortality in cirrhotic patients with ascites. } \\
\text { (HR } 0.812(0.684-0.965)) \text {. }\end{array}$ \\
\hline Durand et al., 2014 [109] & $\begin{array}{l}\text { Prognostic value of muscle atrophy } \\
\text { in cirrhosis }\end{array}$ & Retrospective study & 562 patients with LC & TPMT on CT image & $\begin{array}{l}\text { TPMT/height on CT predicted mortality in cirrhotic } \\
\text { patients, independent of the MELD and MELD-Na } \\
\text { scores. (HR } 0.86(0.78-0.94) \text { and HR } 0.87(0.79-0.95)) \text {. }\end{array}$ \\
\hline Hanai et al., 2015 [110] & $\begin{array}{l}\text { The prevalence of sarcopenia in } \\
\text { patients with LC, Association } \\
\text { between sarcopenia and outcomes. }\end{array}$ & Retrospective study & 130 patients with LC & $\begin{array}{l}\text { L3 skeletal muscle } \\
\text { on CT images }\end{array}$ & $\begin{array}{l}\text { The prevalence of sarcopenia was } 68 \% \text { and } \\
\text { Sarcopenia is significantly associated with mortality } \\
\text { in patients with LC. (HR 3.03) }\end{array}$ \\
\hline $\begin{array}{l}\text { Montano-Loza et al., } \\
2015 \text { [111] }\end{array}$ & $\begin{array}{l}\text { The impact of sarcopenia in } \\
\text { cirrhosis and mortality prediction } \\
\text { of inclusion muscularity } \\
\text { assessment within model for } \\
\text { end-stage liver disease (MELD) }\end{array}$ & Retrospective study & 669 patients with LC & $\begin{array}{l}\text { L3 skeletal muscle } \\
\text { on CT images }\end{array}$ & $\begin{array}{l}\text { Sarcopenia (HR } 0.97(0.96-0.99) \text { ) were associated with } \\
\text { mortality. Modification of MELD to include } \\
\text { sarcopenia is associated with improved prediction of } \\
\text { mortality in patients with cirrhosis, primarily in } \\
\text { patients with low MELD scores. (C-statistics } 0.73 \\
(0.70-0.77) \text { ). }\end{array}$ \\
\hline Hanai et al., 2016 [112] & $\begin{array}{l}\text { The relationship between } \\
\text { time-course change in skeletal } \\
\text { muscle and the prognosis of } \\
\text { patients with LC }\end{array}$ & Retrospective study & 149 patients with LC & $\begin{array}{l}\text { L3 skeletal muscle } \\
\text { on CT images }\end{array}$ & $\begin{array}{c}\text { The relative change in skeletal muscle area per year } \\
(>-3.1 \%) \text { is useful for predicting mortality in patients } \\
\text { with liver cirrhosis. (HR } 2.73(1.43-5.44)) \text {. }\end{array}$ \\
\hline $\begin{array}{l}\text { Nardelli et al., } 2017 \\
\text { [113] }\end{array}$ & $\begin{array}{l}\text { The association between } \\
\text { sarcopenia and HE after TIPS }\end{array}$ & Prospective study & 46 patients with LC & $\begin{array}{l}\text { L3 skeletal muscle } \\
\text { on CT images }\end{array}$ & $\begin{array}{l}\text { Sarcopenia is independently associated with the } \\
\text { development of HE after TIPS (subdistribution HR, } \\
31.3(4.5-218.07)) \text {. }\end{array}$ \\
\hline
\end{tabular}


Table 2. Cont.

\begin{tabular}{|c|c|c|c|c|c|}
\hline \multicolumn{6}{|c|}{ Studies on Patients with Liver Cirrhosis (LC) } \\
\hline Author, Year & Study Aim & Study Design & Study Population & $\begin{array}{l}\text { Method to } \\
\text { Diagnosis } \\
\text { Sarcopenia }\end{array}$ & Outcome \\
\hline Kang et al., 2018 [114] & $\begin{array}{l}\text { Impact of sarcopenia to the } \\
\text { conventional prognostic factors } \\
\text { (MELD, CTP, HVPG) }\end{array}$ & Retrospective study & 452 patients with $\mathrm{LC}$ & $\begin{array}{l}\text { L3 skeletal muscle } \\
\text { on CT images }\end{array}$ & $\begin{array}{l}\text { The prevalence of sarcopenia was } 42 \% \text {. Sarcopenia is } \\
\text { associated with mortality in compensated and early } \\
\text { decompensated cirrhosis. Existing conventional } \\
\text { prognostic factors had limited value in severe } \\
\text { sarcopenia. (MELD, } p=0.182 ; \text { CTP, } p=0.187 \text {; HVPG, } \\
\qquad p=0.077 \text { ). }\end{array}$ \\
\hline \multicolumn{6}{|c|}{ Studies on Patients Who Underwent Liver Transplantation } \\
\hline Author, Year & Study Aim & Study Design & Study Population & $\begin{array}{l}\text { Method to } \\
\text { Diagnosis } \\
\text { Sarcopenia }\end{array}$ & Outcome \\
\hline $\begin{array}{l}\text { Englesbe et al., } 2010 \\
\text { [115] }\end{array}$ & $\begin{array}{l}\text { Association between sarcopenia } \\
\text { and mortality after LT }\end{array}$ & Retrospective study & $\begin{array}{l}163 \text { patients } \\
\text { undergoing } L T\end{array}$ & $\begin{array}{l}\text { psoas muscle at L4 } \\
\text { vertebra on CT } \\
\text { images }\end{array}$ & $\begin{array}{c}\text { Total psoas area strongly correlates with mortality } \\
\text { after LT (HR } 0.274(0.141-0.531))\end{array}$ \\
\hline Krell et al., 2013 [117] & $\begin{array}{l}\text { Association between sarcopenia } \\
\text { and serious infection after LT }\end{array}$ & Retrospective study & $\begin{array}{l}207 \text { patients } \\
\text { undergoing LT }\end{array}$ & TPA on CT images & $\begin{array}{c}\text { Recipient age (HR 1.04), pre-transplant total psoas } \\
\text { muscle area (HR 0.38) and pre-transplant total } \\
\text { bilirubin level (HR 1.05) were independently } \\
\text { associated with the risk of developing } \\
\text { severe infections. }\end{array}$ \\
\hline Tsien et al., 2014 [118] & $\begin{array}{l}\text { The effect of changes in skeletal } \\
\text { muscle mass on outcomes after LT }\end{array}$ & Prospective study & $\begin{array}{l}53 \text { patients } \\
\text { undergoing } L T\end{array}$ & $\begin{array}{l}\text { Psoas and } \\
\text { paraspinal muscles } \\
\text { on CT images }\end{array}$ & $\begin{array}{c}\text { Loss of muscle mass post-OLT increased risk of } \\
\text { diabetes mellitus (HR } 3.1(1.01-9.38)) \text { and a trend } \\
\text { toward higher mortality. }\end{array}$ \\
\hline $\begin{array}{l}\text { Montano-Loza et al., } \\
\quad 2014 \text { [119] }\end{array}$ & $\begin{array}{l}\text { Impact of muscle depletion on } \\
\text { morbidity or mortality after LT }\end{array}$ & Retrospective study & $\begin{array}{l}248 \text { patients } \\
\text { undergoing } \mathrm{LT}\end{array}$ & $\begin{array}{l}\text { L3 skeletal muscle } \\
\text { on CT images }\end{array}$ & $\begin{array}{l}\text { Sarcopenia is predictive of longer hospital stays } \\
\text { ( } 40 \pm 4 \text { vs. } 25 \pm 3 \text { days) and a higher risk of perio- } \\
\text { perative bacterial infection ( } 26 \% \text { vs. } 15 \% \text { ) after LT. }\end{array}$ \\
\hline $\begin{array}{l}\text { Masuda et al., } 2014 \\
{[120]}\end{array}$ & $\begin{array}{l}\text { Impact of sarcopenia on mortality } \\
\text { and sepsis after living donor LT }\end{array}$ & Retrospective study & $\begin{array}{l}204 \text { patients } \\
\text { undergoing LT }\end{array}$ & $\begin{array}{l}\text { Psoas muscle at L3 } \\
\text { vertebra on } \mathrm{CT} \\
\text { images }\end{array}$ & $\begin{array}{l}\text { Sarcopenia is an independent predictor of mortality } \\
\text { (HR 2.06) and sepsis after LDLT (HR 5.31) }\end{array}$ \\
\hline
\end{tabular}


Table 2. Cont.

\begin{tabular}{|c|c|c|c|c|c|}
\hline \multicolumn{6}{|c|}{ Studies on Patients Who Underwent Liver Transplantation } \\
\hline Author, Year & Study Aim & Study Design & Study Population & $\begin{array}{l}\text { Method to } \\
\text { Diagnosis } \\
\text { Sarcopenia }\end{array}$ & Outcome \\
\hline $\begin{array}{l}\text { Hamaguchi et al., } 2014 \\
\text { [121] }\end{array}$ & $\begin{array}{l}\text { Impact of quality and quantity of } \\
\text { skeletal muscle on preoperative CT } \\
\text { on outcomes after LT }\end{array}$ & Retrospective study & $\begin{array}{l}200 \text { patients } \\
\text { undergoing LT }\end{array}$ & $\begin{array}{l}\text { IMAC and PMI on } \\
\text { CT images }\end{array}$ & $\begin{array}{c}\text { High IMAC (OR } 3.898(2.025-7.757)) \text { and low PMI } \\
\text { (OR } 3.635 \text { (1.896-7.174) were independent risk factors } \\
\text { for death after LT. }\end{array}$ \\
\hline $\begin{array}{l}\text { Kalafateli et al., } 2016 \\
\text { [122] }\end{array}$ & $\begin{array}{l}\text { The impact of sarcopenia on post } \\
\text { LT outcomes }\end{array}$ & Retrospective study & $\begin{array}{l}232 \text { patients } \\
\text { undergoing } L T\end{array}$ & $\begin{array}{l}\text { L3-PMI on CT } \\
\text { images }\end{array}$ & $\begin{array}{c}\text { Sarcopenia were independent predictors of Hospital } \\
\text { stay >20 days (OR } 0.996(0.994-0.999)) \text { and } 12 \text { month } \\
\text { mortality (OR } 0.996(0.992-0.999))\end{array}$ \\
\hline \multicolumn{6}{|c|}{ Studies on Patients with Hepatocellular Carcinoma (HCC) } \\
\hline Author, Year & Study Aim & Study Design & Study Population & $\begin{array}{l}\text { Method to } \\
\text { Diagnosis } \\
\text { Sarcopenia }\end{array}$ & Outcome \\
\hline $\begin{array}{c}\text { Meza-Junco et al., } 2013 \\
\text { [123] }\end{array}$ & $\begin{array}{l}\text { Frequency and prognostic } \\
\text { significance of sarcopenia in } \\
\text { patients with HCC. }\end{array}$ & Prospective study & 116 patients with HCC & $\begin{array}{l}\text { L3 SMI on CT } \\
\text { images }\end{array}$ & $\begin{array}{c}\text { Sarcopenia is present in } 30 \% \text { of patients with HCC } \\
\text { and independent risk factor for mortality. (HR, 2.04) } \\
\text { with median survival of } 16 \pm 6 \text { (vs. } 28 \pm 3 \text { months in } \\
\text { nonsarcopenic). }\end{array}$ \\
\hline $\begin{array}{l}\text { Harimoto et al., } 2013 \\
\text { [124] }\end{array}$ & $\begin{array}{l}\text { The effect of sarcopenia on } \\
\text { outcomes after partial hepatectomy } \\
\text { for HCC }\end{array}$ & Retrospective study & 186 patients with HCC & $\begin{array}{l}\text { L3 skeletal muscle } \\
\text { on CT images }\end{array}$ & $\begin{array}{c}5 \text {-year overall survival rate and 5-year recurrence-free } \\
\text { survival rate was } 71 \% \text { vs. } 83.7 \% \text { and } 13 \% \text { vs. } 33.2 \% \text { in } \\
\text { patients with and without sarcopenia, respectively. } \\
\text { Sarcopenia was predictive of an overall survival (HR } \\
3.27(1.39-7.69) \text { ) and recurrence free survival (HR } 0.97 \\
(0.95-1.00) \text { ). }\end{array}$ \\
\hline $\begin{array}{c}\text { Fujiwara et al., } 2015 \\
\text { [125] }\end{array}$ & $\begin{array}{c}\text { Impact of body composition on } \\
\text { HCC }\end{array}$ & Retrospective study & $\begin{array}{c}1257 \text { patients with } \\
\text { different stages of HCC }\end{array}$ & $\begin{array}{l}\text { SMI, mean MA, } \\
\text { visceral adipose } \\
\text { tissue index, sub- } \\
\text { cutaneous adipose } \\
\text { tissue index, VSR } \\
\text { via on CT images }\end{array}$ & $\begin{array}{c}\text { Sarcopenia (HR } 1.52(1.18-1.96)) \text {, intramuscular fat } \\
\text { deposition (HR 1.34 (1.05-1.71)), and visceral } \\
\text { adiposity (HR 1.35 (1.09-1.66)) independently predict } \\
\text { mortality in patients with HCC. }\end{array}$ \\
\hline
\end{tabular}

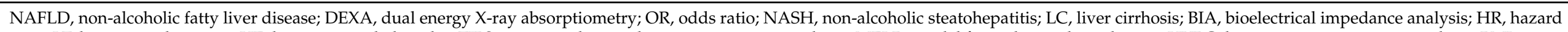

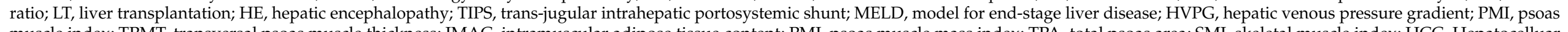

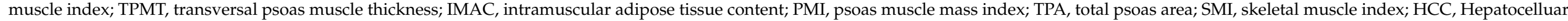
carcinoma; MA, muscle attenuation; VSR, visceral to subcutaneous adipose tissue area ratios. 
In addition, a longitudinal cohort study revealed that increased skeletal mass during the study period had a beneficial effect against the development of NAFLD or improved existing NAFLD at baseline [104]. Muscle mass loss was observed in 40-70\% of liver cirrhosis patients, and most studies reported negative influences of sarcopenia on mortality and liver cirrhosis complications, such as hepatic encephalopathy [105-108,110,112,113]. The degree of sarcopenia was associated with Child-Pugh score in patients with cirrhosis, and sarcopenia was a predictor of survival independently or in combination with the model for end-stage liver disease (MELD) score, especially in patients with low scores $(<15)[109,111,114]$. Unfortunately, after liver transplantation, sarcopenia did not improve and even worsened because of immunosuppressive drugs such as steroids, calcineurin inhibitors, and mammalian target of rapamycin (mTOR) inhibitors [6]. Sarcopenia also had significant impacts on the development of diabetes mellitus, the risk of infection, the length of hospitalization, and mortality in patients who underwent liver transplantation [115-122]. Further, sarcopenia was shown to independently predict mortality, overall survival, and recurrence-free survival in patients with hepatocellular carcinoma [123-125].

\subsection{Molecular Mechanism of Sarcopenia in Chronic Liver Disease}

In normal physiology, skeletal muscle protein turnover is maintained as a balance between protein synthesis and breakdown. mTOR is an essential modulator of translational control, majorly involved in protein synthesis [126]. Exercise, branched chain amino acids (BCAAs), as well as various hormones, including testosterone, insulin, and IGF-1, activate the mTOR pathway in muscle cells through protein kinase $B$, which subsequently triggers several intracellular pathways for muscle protein synthesis, including p70 ribosomal S6 kinase 1 (S6K1) and eukaryotic initiation factor 4E binding protein (4E-BP1) [126]. In addition, the proliferation of muscle satellite cells, which are muscle fiber precursors, is critical for muscle growth and is activated in response to IGF-1 and BCAAs through protein kinase B [126,127].

In contrast, myostatin, a transforming growth factor beta (TGF- $\beta$ ) superfamily member produced in muscle, inhibits protein synthesis by maintaining satellite cells in a quiescent state, activating SMAD family transcription factors 2 and 3 (SMAD 2/3), and stimulating proteolysis via forkhead box $\mathrm{O}$ transcription factors (FoxOs) associated with the ubiquitinproteasome pathway (UPP) and autophagy $[128,129]$. Impaired mitochondrial function, insulin resistance, and reactive oxygen species (ROS) also stimulate autophagy.

\subsubsection{Sarcopenia in Non-Cirrhotic Liver Disease}

Sarcopenia and NAFLD share multiple pathophysiological mechanisms, including insulin resistance, chronic inflammation, cellular senescence, and oxidative stress [5]. As muscle cells are major targets of insulin as well as an essential amino acid reservoir for energy metabolism, sarcopenia affects various metabolic processes and is implicated in insulin resistance, NAFLD, and obesity [5]. The concept of sarcopenic obesity highlights this relationship [130]. With aging, muscle mass steadily decreases and is replaced by fat, which contributes to a reduction in physical activity and lower energy expenditure, especially the resting metabolic rate [131]. Therefore, muscle dysfunction and low muscle mass promote insulin resistance and NAFLD. In addition, physical inactivity combined with age-related comorbidity and estrogen changes during menopause contribute to NAFLD via fat mass deposition and sarcopenia [132].

In insulin resistance status, which is tightly associated with NAFLD pathogenesis, the inactivated insulin receptor pathway leads to a decrease in phosphorylated AKT (pAKT) levels, resulting in impaired protein synthesis, enhanced protein degradation and atrophy through autophagy and the UPP pathway [133]. As an anabolic hormone produced by hepatocytes and myocytes, IGF-1 stimulates muscle protein synthesis by activating the mTOR pathway through AKT phosphorylation and the suppression of FoxO1, muscle ring finger 1 (MuRF1), and the antrogin-1 pathway of protein catabolism [134,135]. Previous animal studies reported that serum and liver IGF-1 levels were decreased in fatty liver 
disease caused by insulin resistance, and NAFLD models with low IGF-I levels exhibited impaired muscle strength, function, and lower muscle fiber diameters [136].

NAFLD, insulin resistance, and obesity increase adipocyte lipolysis and have a stimulatory effect on immune cells such as macrophages and lymphocytes, leading to a chronic state of low-grade inflammation with increased production of proinflammatory cytokines, including TNF- $\alpha$ and IL-6. Shortly after exercise, IL-6 regenerates muscle cells through satellite cell regulation and glucose metabolism activation. In contrast, IL-6 promotes muscle catabolism in concert with TNF- $\alpha$ under chronic inflammatory states, such as infection and obesity $[137,138]$. Furthermore, TNF- $\alpha$ inhibits AMP-activated protein kinase (AMPK) signaling in muscle and insulin receptor autophosphorylation in fat tissue and the liver, which promotes insulin resistance [139,140]. Several adipokines, most notably adiponectin and leptin, are associated with muscle and liver metabolism. Adiponectin enhanced lipolysis, reducing inflammation and stellate cell activation in the liver, which in turn promoted glucose uptake and fatty acid oxidation in muscle [141,142]. Leptin activated stellate cells and fibrogenesis in the liver, while promoting IGF-1 activation and suppressing myostatin levels, which fostered myoblast proliferation and an increase in muscle mass [143]. In the state of insulin resistance, adiponectin is decreased, and leptin resistance is observed. Adipocytes were shown to activate the renin-angiotensin-aldosterone system (RAAS), in turn promoting insulin resistance and metabolic syndrome [144,145]. RAAS also influenced sarcopenia by inhibiting muscle regeneration and proliferation, while promoting muscle protein degradation via the UPP system [146,147]. Myostatin, a representative myokine related to sarcopenia, increased adipose tissue and suppressed adiponectin production as well as fatty acid oxidation in adipocytes. Myostatin knockout mice exhibited AMPK activation in the liver, adipocytes, and muscle, resulting in the restoration of insulin sensitivity [148-151]. Irisin, which is the cleaved extracellular domain of the muscle transmembrane fibronectin type III domain-containing protein 5 (FNDC5), increased during exercise, and promoted glucose uptake through the AMPK pathway $[152,153]$. Irisin also enhanced energy expenditure through uncoupling protein 1 (UCP1) activation and the browning of white fat in an animal model [153]. A recent study on single nucleotide polymorphisms reported the association between impaired irisin expression and severe hepatic steatosis [154]. Lee et al. reported an association between sarcopenia and NAFLD independent of insulin resistance or obesity, suggesting an effect of myokines on NAFLD [99].

\subsubsection{Sarcopenia in Liver Cirrhosis}

The liver is an essential organ for carbohydrate, protein, and lipid metabolism. As the hepatic glucose reservoir is reduced, liver cirrhosis is regarded as a state of accelerated glucose starvation. In response, amino acids derived from skeletal muscle proteolysis are utilized for gluconeogenesis, which leads to the reduced BCAA levels observed in liver cirrhosis [155]. BCAAs including leucine, isoleucine, and valine, are essential for muscle mass preservation [155]. In particular, leucine activates protein synthesis via the mTOR pathway and is preferentially utilized for energy production in skeletal muscle [147]. Thus, the reduced BCAA levels in liver cirrhosis caused sarcopenia through muscle degradation [156]. Given that the liver is a crucial organ for ammonia disposal, the progression of portosystemic shunting and hepatocellular dysfunction in liver cirrhosis resulted in impaired ureagenesis and subsequent hyperammonemia [157]. In the hyperammonemic state, muscles convert ammonia to glutamate and glutamine via glutamine synthetase [158-160]. However, unless ureagenesis is recovered, no permanent ammonia disposal can occur, and circulating glutamine is just used in the process of ammoniagenesis, while hyperammonemia persists. Since carbon molecules from the tricarboxylic acid (TCA) cycle in muscle are relocated to other tissues through this pathway, bioenergetic dysfunction, impaired proteostasis, and sarcopenia develop in skeletal muscle [161]. Increased ammonia uptake in skeletal muscle contributes to molecular changes that favor sarcopenia, leading to a vicious cycle with decreased ammonia clearance and worsening liver cirrhosis outcome [161-164]. 
A large body of literature has proposed multiple pathophysiological mechanisms for hyperammonemia-induced sarcopenia. Qiu et al. demonstrated that serum and skeletal muscle ammonia levels were elevated in patients with cirrhosis, and hyperammonemia influenced myostatin expression via p65-NF-kB-dependent signaling [165]. Nishikawa et al. revealed that increased serum myostatin levels were associated with higher serum ammonia, a high Child-Pugh score, and were inversely related to psoas muscle mass [127]. In the hyperammonemia state, myostatin was suggested to inhibit protein synthesis not through the UPP system but via autophagy-mediated proteolysis [164]. Further, ammoniaassociated mitochondrial dysfunction and increased ROS are regarded as potential triggers for the activation of autophagy [166]. Ammonia is converted to glutamate with the TCA cycle intermediate, $\alpha$-ketoglutarate $(\alpha-K G)$ in mitochondria, followed by the SLC7A5mediated conversion of glutamate to glutamine yielding leucine, which occurs in skeletal muscle [167-169]. Reduced $\alpha-\mathrm{KG}$ from this reaction and hyperammonemia disrupted mitochondrial function and reduced adenosine triphosphate (ATP), with muscle mass and contractile function subsequently deteriorating [170]. The cellular stress response to reduced intracellular amino acid levels also influences sarcopenia. In alcoholic liver cirrhosis, phosphorylation and activation of general control non-depressible 2 (GCN2), an amino acid deficiency sensor, was reported [156]. Activation of GCN2 phosphorylated the alpha subunit of eukaryotic initiation factor 2 (eIF2a), which subsequently suppressed mRNA translation, impaired mTOR signaling, and suppressed protein synthesis [171,172]. Although the exact mechanism of GCN2 activation in hyperammonemia has not been elucidated, low BCAA levels have been proposed as potential mediators [173,174]. It is well known that testosterone increases muscle mass and enhances muscle protein synthesis through IGF-1 and subsequent mTOR activation [175,176]. Growth hormone and testosterone also contribute to sustained satellite cell activity by suppressing myostatin secretion and signaling [177,178]. However, increased serum aromatase activity in liver cirrhosis reduced serum testosterone levels, which was suggested as a potential contributor to sarcopenia, although whether these hormonal changes have an actual influence on protein synthesis and myostatin expression is unknown [179]. Recently, the gut microbiome has attracted major interest with regard to the pathophysiology of sarcopenia. In liver cirrhosis, compositional changes in the gut microbiota increased intestinal permeability and endotoxemia, while impairing SCFA production and antioxidant function [180-182]. These functional changes contributed to the development of sarcopenia through anabolic resistance, chronic inflammation with elevated IL- 6 and TNF- $\alpha$, altered mitochondrial function, as well as oxidative stress [3,183].

\section{Osteosarcopenia}

\subsection{Prevalence of Osteosarcopenia}

With a global increase in aging populations, evidence for osteosarcopenia in clinical practice is growing. In community-dwelling elderly adults, the prevalence of osteosarcopenia ranged from $18 \%$ in China to $40 \%$ in Australia [11]. In addition, patients with osteosarcopenia were more susceptible to fracture and frailty [16,184]. A study from Korea showed that $27.2 \%$ of elderly adults with hip fractures had osteosarcopenia, and these patients had a higher 1-year mortality rate $(15.1 \%)$ compared to those with osteoporosis $(5.1 \%)$ or sarcopenia $(10.3 \%)$ alone [17]. Recently, several studies reported sarcopenia as a potential predictor of osteoporosis and reduced exercise tolerance in chronic liver disease, hepatitis C, as well as liver cirrhosis [185-188]. However, literature on the prevalence and clinical implications of osteosarcopenia in chronic liver disease remains limited. Seaki et al. reported that the prevalence of osteosarcopenia was approximately $20 \%$ in patients with chronic liver disease, with osteoporosis increasing the risk of vertebral fracture in these patients (Table 3) [189,190]. 
Table 3. Representative clinical studies for osetosarcopenia in chronic liver disease.

\begin{tabular}{|c|c|c|c|c|c|}
\hline $\begin{array}{l}\text { Author, Year } \\
\text { [Reference] }\end{array}$ & Study Aim & Study Design & Study Population & $\begin{array}{c}\text { Method to } \\
\text { Diagnosis } \\
\text { Osteosarcopenia }\end{array}$ & Outcome \\
\hline Santos et al., 2016 [188] & $\begin{array}{l}\text { To evaluate whether handgrip } \\
\text { strength, bone, and liver tests may } \\
\text { be useful as predictors of bone } \\
\text { disease in outpatients with LC }\end{array}$ & Prospective study & 129 patients with LC & $\begin{array}{c}\text { DEXA, } \\
\text { dynamometer }\end{array}$ & $\begin{array}{l}\text { For lumbar spine, only low handgrip strength and } \\
\text { high PTH levels were clearly related to low T scores. }\end{array}$ \\
\hline $\begin{array}{l}\text { Hayashi et al., } 2018 \\
\text { [185] }\end{array}$ & $\begin{array}{l}\text { Association between sarcopenia } \\
\text { and osteoporosis in patients } \\
\text { with CLD }\end{array}$ & Retrospective study & $\begin{array}{l}112 \text { CLD patients } \\
\text { including } 40 \text { cirrhotic } \\
\text { patients }\end{array}$ & BIA and DEXA & $\begin{array}{l}\text { The sarcopenia rate was } 13 \% \text {, and the osteoporosis } \\
\text { and osteopenia rates were } 17 \% \text { and } 65 \% \text {, respectively. } \\
\text { Sarcopenia was significantly associated with the BMD } \\
\text { of the lumbar spine and the femur neck. Sarcopenia } \\
\text { (OR 6.16) and cirrhosis (OR } 15.8 \text { ) were independent } \\
\text { risk factors for osteoporosis. }\end{array}$ \\
\hline $\begin{array}{l}\text { Hayashi et al., } 2018 \\
\text { [186] }\end{array}$ & $\begin{array}{l}\text { Association between loss of } \\
\text { skeletal muscle mass and clinical } \\
\text { factors such as osteoporosis in } \\
\text { patients with chronic liver disease. }\end{array}$ & $\begin{array}{l}\text { Cross-sectional } \\
\text { study }\end{array}$ & $\begin{array}{l}112 \text { HCC patients } \\
\text { undergoing } \\
\text { hepatectomy }\end{array}$ & DEXA & $\begin{array}{c}\text { The T-score and PeakVO2 was significantly lower in } \\
\text { the low skeletal mass index (SMI) group. T-score (OR } \\
3.508(1.074-11.456)) \text { and PeakVO2 (OR } 3.512 \\
(1.114-11.066)) \text { were significantly related to SMI, } \\
\text { independent of age and sex. }\end{array}$ \\
\hline Saeki et al., 2020 [189] & $\begin{array}{l}\text { Association between } \\
\text { osteosarcopenia and frailty in } \\
\text { patients with CLD }\end{array}$ & $\begin{array}{l}\text { Cross-sectional } \\
\text { study }\end{array}$ & 291 patients with CLD & DEXA & $\begin{array}{l}49(16.8 \%) \text { and } 81(27.8 \%) \text { had osteosarcopenia and } \\
\text { frailty, respectively. Frailty was an independently } \\
\text { associated with osteosarcopenia (OR 9.837), and vice } \\
\text { versa (OR 10.069) and increased the risk of vertebral } \\
\text { fracture in patients with CLD. }\end{array}$ \\
\hline
\end{tabular}

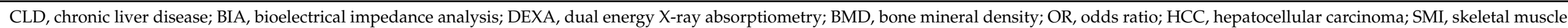
index; $\mathrm{CHC}$, chronic hepatitis $\mathrm{C}$; LC, liver cirrhosis; PTH, parathyroid hormone. 


\subsection{Crosstalk between Osteoporosis and Sarcopenia}

As discussed above, sarcopenia and osteoporosis share common risk factors and underlying pathophysiological mechanisms, including insulin resistance, decreased anabolic hormones, such as IGF-1 and testosterone, and upregulated inflammatory cytokines such as IL-1, IL-6, and TNF- $\alpha$, which may contribute to the development of osteosarcopenia in liver disease, although their involvement has rarely been proven in osteosarcopenia models. Furthermore, sophisticated bidirectional crosstalk between muscle and bone consisting of not only mechanical interaction, but also paracrine and endocrine communication, plays a role in bone and muscle homeostasis (Figure 1). The mechanical perspective is based on the fact that muscle force is the major mechanical component to generate strain in bone. Therefore, decreased muscle function and performance result in decreased skeleton load and a subsequent deterioration of bone density. In addition, it is well known that muscle paralysis, atrophy, or immobilization promote both bone loss and osteoporosis [12]. However, sarcopenia does not always precede osteoporosis, and muscle mass changes alone cannot cause osteoporosis and vice versa. Vitamin D, Vitamin K $\downarrow$ Toxic materials: bilirubin, bile acid, alcohol, iron, cupper $\uparrow$ Sclerostin $\uparrow$

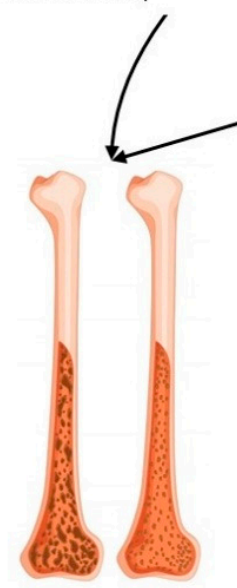

osteoporosis

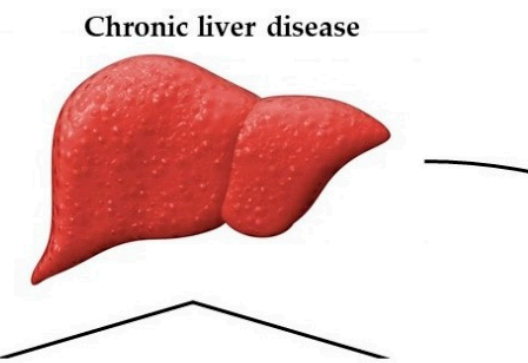

Proinflammatory cytokines (IL-1,IL-6, TNF- $\alpha$ ) $\uparrow$

Anabolic hormones (IGF-1, testosterone) $\downarrow \leftarrow$ SARMs Insulin resistance $\uparrow$ Dysbiosis Physical inactivity

Osteocalcin, RANK/RANKL $\leftarrow$ RANKL inhibitor TGF- $\beta$, Wnt $/ \beta$-catenin pathway

Myostatin $\leftarrow$ Myostatin antagonist irisin, BAIBA
Irisin $\downarrow$

Hyperammonemia: myostatin $\uparrow$ Nutritional deficiency: Low BCAA Hepatic gluconeogenesis $\uparrow$

Figure 1. Overview of mechanism of osteosarcopenia in chronic liver disease and potential therapeutic strategies. RANKL, receptor-activator of nuclear factor kappa ligand; OPG, osteoprotegerin; IGF-1, Insulin-like growth factor-1; BCAA, branched chain amino acids; BAIBA, beta-aminoisobutyric acid; SARM, Selective androgen receptor modulator.

Several mechanisms were proposed to underpin biochemical communication between sarcopenia and osteoporosis via the musculoskeletal secretome. Polymorphisms in the genes encoding glycine- $\mathrm{N}$-acyltransferase (GLYAT), methyltransferase-like 21C (METTL21C), myostatin, $\alpha$-actinin 3, proliferator-activated receptor gamma coactivator 1-alpha (PGC-1 $\alpha$ ), and myocyte enhancer factor 2C (MEF-2C) were related to bone and muscle loss [14,191]. In addition, peak muscle and bone volume in early life by genetic traits could postpone the time of sarcopenia and osteoporosis in geriatrics [10]. Guo et al. reported that GLYAT genes influence both bone and muscle remodeling through the regulation of glucose and energy metabolism [192]. Among METTL2 family of methyltransferase superfamily, METTL21C was proposed as having pleiotropic effects on bone and muscle 
through the NF-kB signaling pathway, which contributed to skeletal muscle atrophy [193]. Downregulation of this gene promoted reduced myogenic differentiation, impairment of calcium homeostasis in myocytes, and increased susceptibility of osteocytes to apoptotic agents such as dexamethasone [193]. MEF-2C, a transcription factor, which has been reported as a potential regulator of skeletal muscle gene expression, is also associated with bone homeostasis [194,195]. It regulates sclerostin, which inhibits osteoblastic bone formation, and modulates osteoclastic bone resorption. Further, deletion of the gene in osteocytes resulted in higher bone density [195].

As endocrine organs, muscles secrete various myokines, including myostatin, leukemia inhibitory factors (LIF), IGF-1, fibroblast growth factor 2 (FGF2), follistatin-like protein 1 , brain-derived neurotrophic factor (BDNF), and irisin, which influence bone remodeling [196]. Myostatin acts as a negative regulator not only in muscle but also in bone by directly promoting the recruitment and differentiation of osteoclasts [197]. BMD was significantly increased in myostatin-deficient mice, and the use of myostatin inhibitors restricted bone loss as well as muscle loss in a number of musculoskeletal disease models [198-200]. Through its pro-myogenic effect, irisin also controlled bone mass by regulating energy metabolism and promoting osteoblast differentiation, resulting in increased bone cortical mass [201]. Recombinant irisin treatment increased cortical mineral density and bone strength in mice with an upregulation of pro-osteoblastic genes and a reduction of osteoblast inhibitors [202]. Recently, Kitase et al. demonstrated that beta-aminoisobutyric acid (BAIBA), a muscle metabolite secreted by contracting muscle, also played a role in preventing ROS-induced osteocyte cell death and preserved bone mass during immobilization [203].

Osteokines secreted from osteocytes, including osteocalcin, also have an influence on muscle. Osteocalcin produced in mature osteoblasts or osteocytes was involved in muscle mass remodeling by regulating glucose and energy metabolism as well as stimulating testosterone synthesis [204]. Mice deficient for GPCR6A, a G-protein-coupled receptor of osteocalcin, exhibited lower muscle mass. In contrast, mice lacking embryonic stem cell phosphatase, an enzyme that impairs osteocalcin activity, had increased muscle mass [204]. In addition, exogenously administered osteocalcin reversed the aging-associated decrease of exercise capacity and muscle strength in mice [205].

RANK is also expressed in skeletal muscle and suppresses skeletal muscle mass and function by restricting myogenic differentiation through the NF- $\mathrm{kB}$ pathway [206]. RANKL, an important modulator of bone resorption, was suggested to inhibit muscle function and mass, while RANKL inhibition ameliorated these effects, improving insulin sensitivity in osteoporotic mice and humans [207]. TGF- $\beta$ is mainly produced from boneforming osteoblasts and has an effect on perilacunar matrix modeling. In osteocytes, decreased TGF- $\beta$ signaling caused bone fragility. TGF- $\beta$ is also involved in bone-to-muscle communication [208]. Pathological TGF- $\beta$ release from bone in breast cancer patients caused muscle weakness through reduced $\mathrm{Ca}^{++}$-induced muscle strength production [209].

Finally, the Wnt/ $\beta$-catenin pathway regulates bone formation and is an important mediator of mechanical loading transmission at the bone surface [210,211]. Since secreted Wnt modulates cell proliferation, differentiation, and survival, the Wnt/ $\beta$-catenin signaling pathway is known to play a significant role in skeletal muscle development, growth, and generation [212,213]. Huang et al. demonstrated that WNT3A produced by osteocytes promoted the differentiation of $\mathrm{C} 2 \mathrm{C} 12$ myoblasts [214]. In addition, Wnt signaling is thought to be associated with satellite cell differentiation by promoting muscle regulatory factors during embryogenesis [12].

\subsection{Management}

\subsubsection{Exercise and Nutritional Support}

Exercise may be considered for maintaining and improving skeletal muscle mass and BMD in chronic liver disease. Physical and electrical stimulation are known to positively influence osteogenesis during exercise [14]. A previous study reported the positive effect 
of active walking and strength training on BMD, and exercise could decrease the risk of falling and fracture in patients with osteoporosis $[215,216]$. In addition, several randomized controlled trials (RCTs) have shown that progressive resistance training stimulates muscle protein synthesis, enhancing muscle mass and strength in elderly patients with sarcopenia $[217,218]$. Roman et al. reported that combination treatment with moderate exercise and leucine supplementation increased exercise capacity and muscle mass in patients with liver cirrhosis [219]. Taken together, exercise-based treatment could improve skeletal muscle mass as well as bone density in patients with chronic liver disease. However, depending liver disease severity, some patients may experience obstacles in undertaking adequate exercise, particularly those suffering from end-stage liver disease.

For the nutritional support of the patient with osteoporosis, persistent calcium intake at a dosage of 1000 to $1500 \mathrm{mg}$ /day as well as oral 25-hydroxy vitamin D supplementation of 400-800 IU/day or $260 \mu \mathrm{g}$ every 2 weeks is recommended [2]. Since the disturbance of glucose and protein metabolism is a major pathophysiological mechanism of sarcopenia, dietary intervention and protein as well as BCAA supplementation are frequently proposed for the treatment of sarcopenia. Small frequent meals at short intervals instead of simply increasing caloric intake are conducive to increasing caloric intake and decreasing gluconeogenesis [6]. Tisen et al. showed that leucine-enriched BCAA supplementation significantly improved mTOR signaling and reduced muscle autophagy that contributes to enhancing muscle protein synthesis in patients with alcoholic cirrhosis. Also, L-leucine enriched BCAA supplementation reversed the GCN2-eIF2a phosphorylation and impaired mTOR signaling [171]. However, the beneficial effect of leucine-enriched BCAA treatment varied according to either accompanying improvements in metabolic parameters, or age $[155,220]$. Tryptophan, another essential amino acid, is associated with muscle mass homeostasis by regulating GH-IGF-1 signaling [221]. Though previous animal studies showed that a tryptophan-enriched diet promoted muscle protein synthesis in swine and tryptophan supplementation stimulated skeletal muscle signaling in vivo, which increased IGF-1, leptin as well as follistatin, and expression of myogenic genes in vitro, the effect of tryptophan treatment on sarcopenic patients with liver disease is rarely known [222,223]. In addition, glutamine, which plays an important role in protein metabolism, seems ineffective in preventing skeletal muscle loss in experimental studies [224-226]. Therefore, further investigations are warranted to determine if the clinical use of protein supplementation is effective for the treatment of sarcopenia in liver disease.

\subsubsection{Pharmacological Treatment}

Although no pharmacological therapy has been approved for the treatment of patients with sarcopenia, effective osteoporosis therapeutics are well established. Widely used pharmacological treatments for osteoporosis include antiresorptive (denosumab, bisphosphate), anabolic (teriparatide, abaloparatide), sclerostin-inhibiting (romosozumab), and hormonal (hormone replacement therapy, selective estrogen receptor modulators) agents [78,227] (for a detailed review of these, see [78,227]) Regarding sarcopenia in chronic liver disease, few studies on ammonia lowering therapy reported positive effects on muscle mass increase. Kumar et al. reported that ammonia reduction using L-ornithine L-aspartate (LOLA) increased lean body mass, grip strength, and reversed myostatin levels as well as autophagy markers by reducing ammonia levels [228]. Rifaximin, which is a non-absorbable antibiotic used for the reduction of ammonia levels, was suggested to inhibit myostatin expression [229].

Recently, various novel treatments have been explored for therapeutically targeting not only bone, but also muscle. Denosumab, a humanized monoclonal antibody against RANKL, showed promising effects not only in protecting bone resorption and increasing bone mass but also by improving muscle strength and mass in postmenopausal women with osteoporosis [207]. A recent study of community-dwelling elderly adults reported that denosumab significantly improved balance, fear of falling, and physical function compared to zoledronic acid treatment [230]. Denosumab may thus have potential as a 
osteosarcopenia therapeutic, and further studies are necessary to confirm its effects on muscle mass and function.

Although testosterone has an anabolic effect on both bone and muscle, clinical studies have rarely reported the benefit of testosterone treatment on musculoskeletal disease. Selective androgen receptor modulators (SARMs) exhibited anabolic effects on muscle and bone. In addition, since SARMs selectively target tissue, there were little androgenic side effects [231]. In a recent phase II trial, VK5211, Ristic et al. reported that oral non-steroid SARMs improved lean muscle mass and increased bone formation with procollagen type $1 \mathrm{~N}$ propeptide (P1NP), which highlights its potential for the treatment of osteosarcopenia [11].

Targeting myostatin, which is an important negative regulator of bone and muscle, has also been rigorously studied. ACE-031 is a soluble form of activin receptor type IIB, which binds myostatin to neutralize its effects. A previous study showed that ACE-031 treatment was well tolerated and increased bone formation markers, improving lean body mass in postmenopausal women [232]. In a phase II trial in elderly adults with a history of falling, treatment with a humanized myostatin antibody increased lean body mass and improved performance-based measures associated with muscle strength [233]. However, as myostatin is also present in cardiac tissue, myostatin targeted treatment may cause adverse events such as cardiomyopathy [234]. Therefore, further studies to clarify the efficacy and long-term safety of myostatin inhibition beyond experimental studies are warranted before its clinical use. Other pharmacological treatments, including growth hormone and IGF-1, have been investigated for the treatment osteoporosis and sarcopenia, but beneficial effects were not observed [14]. We summarize current pharmacologic treatments of osteoporosis, sarcopenia, and osterosarcopenia in Table 4.

Table 4. Pharmacologic treatments of osteoporosis, sarcopenia, and osteosarcopenia.

\begin{tabular}{|c|c|c|}
\hline Disorders & Effect & Agents \\
\hline \multirow[t]{8}{*}{ Osteoporosis } & Inhibit bone resorption & Calcium \\
\hline & Inhibit bone resorption & Vitamin D \\
\hline & Inhibit bone resorption & Calcitonin \\
\hline & Inhibit bone resorption & SERMs (ex, raloxifene) \\
\hline & Inhibit bone resorption & $\begin{array}{c}\text { Bisphosphates (ex, alendronate, zoledronic acid, } \\
\text { ibandronate) }\end{array}$ \\
\hline & Inhibit bone resorption & Anti-RANKL antibody (ex, denosumab) \\
\hline & Activate bone formation & PTH (ex, teriparatide) \\
\hline & Activate bone formation & Sclerostin inhibitors (ex, romosozumab) \\
\hline \multirow[t]{5}{*}{ Sarcopenia } & Reduce Ammonia & L-ornithine L-aspartate \\
\hline & Reduce Ammonia & Rifaximin \\
\hline & Increase muscle protein synthesis & Testosterone \\
\hline & Increase muscle protein synthesis & Myostatin antagonists (ex, follistatin) \\
\hline & Increase muscle protein synthesis & IGF-1 antagonist \\
\hline \multirow[t]{3}{*}{ Osteosarcopenia } & $\begin{array}{l}\text { Inhibit bone resorption } \\
\text { Increase muscle protein synthesis (insulin sensitivity) }\end{array}$ & Anti-RANKL antibody (ex, denosumab) \\
\hline & Activate bone and muscle formation & SARMs (ex, VK5211) \\
\hline & Activate bone and muscle formation & Myostatin antagonists (ex, ACE-031) \\
\hline
\end{tabular}

SERMs; selective estrogen receptor modulators; RANKL, receptor-activator of nuclear factor kappa ligand; PTH, parathyroid hormones; SARMs, Selective androgen receptor modulator.

\section{Conclusions}

A number of previous studies have demonstrated that osteoporosis and sarcopenia are common musculoskeletal disorders which negatively affect the quality of life, and increasing morbidity and mortality in patients with chronic liver disease. However, the awareness of these musculoskeletal disorders in liver disease is frequently neglected in clinical practice and current management guidelines for various liver diseases such as viral hepatitis, decompensated liver cirrhosis did not state the managements for these 
musculoskeletal disorders. In this review, we addressed the molecular mechanisms of osteoporosis, sarcopenia, and osteosarcopenia in chronic liver disease, to increase the understanding and attentions of these musculoskeletal disorders, especially in liver disease. Increased bone resorption through the receptor activator of nuclear factor kappa (RANK)RANK ligand (RANKL)-osteoprotegerin (OPG) system and upregulation of inflammatory cytokines are considered important mechanisms for osteoporosis in non-alcoholic fatty liver disease (NAFLD) and viral hepatitis. Osteoporosis in cholestatic liver disease is associated with impaired bone formation, increased bilirubin and sclerostin, and lower insulin-like growth factor-1. Sarcopenia in NAFLD is associated with insulin resistance and obesity, whereas in liver cirrhosis, it is influenced by hyperammonemia, low amount of branched chain amino acids, and hypogonadism. In addition, osteoporosis and sarcopenia shared common underlying mechanisms, including insulin resistance, decreased anabolic hormones, such as IGF-1 and testosterone, increased inflammatory cytokines, including IL-1, IL-6, and TNF- $\alpha$, as well as dysbiosis. Moreover, biochemical crosstalk between bone and muscle through various signaling pathways have been elucidated, highlighting osteosarcopenia as a prevalent combination of osteoporosis and sarcopenia. Given the significant roles of these musculoskeletal disorders as prognostic predictors and their major involvement in liver disease pathogenesis, increased knowledge for the molecular mechanism of these musculoskeletal disorders could be contribute to improvement of not only musculoskeletal disorder itself, but also prognosis of liver disease by promoting the clinical application of existing potential therapeutics for these musculoskeletal disorders in patients with liver disease, and further development the effective therapies targeting the pathophysiological mechanism involved.

Author Contributions: Conceptualization, D.J.K.; search and review of article, Y.J.Y. and D.J.K.; writing-original draft preparation, Y.J.Y. and D.J.K.; writing-review and editing, Y.J.Y. and D.J.K. All authors have read and agreed to the published version of the manuscript.

Funding: This research was supported by Basic Science Research Program (2020R1A6A1A03043026) through the National Research Foundation of Korea (NRF) funded by the Ministry of Education.

Data Availability Statement: Data is contained within the article.

Conflicts of Interest: The authors declare no conflict of interest.

\section{References}

1. Guañabens, N.; Parés, A. Osteoporosis in chronic liver disease. Liver Int. 2018, 38, 776-785. [CrossRef]

2. Jeong, H.M.; Kim, D.J. Bone Diseases in Patients with Chronic Liver Disease. Int. J. Mol. Sci. 2019, 20, 4270. [CrossRef] [PubMed]

3. Ebadi, M.; Bhanji, R.A.; Mazurak, V.C.; Montano-Loza, A.J. Sarcopenia in cirrhosis: From pathogenesis to interventions. J. Gastroenterol. 2019, 54, 845-859. [CrossRef] [PubMed]

4. Meyer, F.; Bannert, K.; Wiese, M.; Esau, S.; Sautter, L.F.; Ehlers, L.; Aghdassi, A.A.; Metges, C.C.; Garbe, L.-A.; Jaster, R.; et al. Molecular Mechanism Contributing to Malnutrition and Sarcopenia in Patients with Liver Cirrhosis. Int. J. Mol. Sci. 2020, $21,5357$. [CrossRef] [PubMed]

5. Fernández-Mincone, T.; Contreras-Briceño, F.; Espinosa-Ramírez, M.; García-Valdés, P.; López-Fuenzalida, A.; Riquelme, A.; Arab, J.P.; Cabrera, D.; Arrese, M.; Barrera, F. Nonalcoholic fatty liver disease and sarcopenia: Pathophysiological connections and therapeutic implications. Expert Rev. Gastroenterol. Hepatol. 2020, 14, 1-17. [CrossRef]

6. Jindal, A.; Jagdish, R.K. Sarcopenia: Ammonia metabolism and hepatic encephalopathy. Clin. Mol. Hepatol. 2019, $25,270-279$. [CrossRef] [PubMed]

7. Carey, E.J.; Lai, J.C.; Sonnenday, C.; Tapper, E.B.; Tandon, P.; Duarte-Rojo, A.; Dunn, M.A.; Tsien, C.; Kallwitz, E.R.; Ng, V.; et al. A North American Expert Opinion Statement on Sarcopenia in Liver Transplantation. Hepatology 2019, 70, 1816-1829. [CrossRef]

8. Hsu, C.-S.; Kao, J.-H. Sarcopenia and chronic liver diseases. Expert Rev. Gastroenterol. Hepatol. 2018, 12, 1229-1244. [CrossRef] [PubMed]

9. Dasarathy, S.; Merli, M. Sarcopenia from mechanism to diagnosis and treatment in liver disease. J. Hepatol. 2016, 65, 1232-1244. [CrossRef]

10. Kirk, B.; Zanker, J.; Duque, G. Osteosarcopenia: Epidemiology, diagnosis, and treatment-Facts and numbers. J. Cachex-Sarcopenia Muscle 2020, 11, 609-618. [CrossRef]

11. Kirk, B.; Al Saedi, A.; Duque, G. Osteosarcopenia: A case of geroscience. Aging Med. 2019, 2, 147-156. [CrossRef] [PubMed]

12. Bonewald, L. Use it or lose it to age: A review of bone and muscle communication. Bone 2019, 120, 212-218. [CrossRef] 
13. Picca, A.; Calvani, R.; Manes-Gravina, E.; Spaziani, L.; Landi, F.; Bernabei, R.; Marzetti, E. Bone-Muscle Crosstalk: Unraveling New Therapeutic Targets for Osteoporosis. Curr. Pharm. Des. 2018, 23, 6256-6263. [CrossRef]

14. Hirschfeld, H.P.; Kinsella, R.; Duque, G. Osteosarcopenia: Where bone, muscle, and fat collide. Osteoporos. Int. 2017, 28, 2781-2790. [CrossRef]

15. Kawao, N.; Kaji, H. Interactions Between Muscle Tissues and Bone Metabolism. J. Cell. Biochem. 2015, 116, 687-695. [CrossRef]

16. Wang, Y.-J.; Wang, Y.; Zhan, J.-K.; Tang, Z.-Y.; He, J.-Y.; Tan, P.; Deng, H.-Q.; Huang, W.; Liu, Y.-S. Sarco-Osteoporosis: Prevalence and Association with Frailty in Chinese Community-Dwelling Older Adults. Int. J. Endocrinol. 2015, 2015, 482940. [CrossRef] [PubMed]

17. Yoo, J.-I.; Kim, H.; Ha, Y.-C.; Kwon, H.-B.; Koo, K.-H. Osteosarcopenia in Patients with Hip Fracture Is Related with High Mortality. J. Korean Med. Sci. 2018, 33, e27. [CrossRef] [PubMed]

18. Collier, J. Bone disorders in chronic liver disease. Hepatology 2007, 46, 1271-1278. [CrossRef] [PubMed]

19. Menon, K.; Angulo, P.; Weston, S.; Dickson, E.; Lindor, K.D. Bone disease in primary biliary cirrhosis: Independent indicators and rate of progression. J. Hepatol. 2001, 35, 316-323. [CrossRef]

20. Guañabens, N.; Parés, A.; Ros, I.; Caballería, L.; Pons, F.; Vidal, S.; Monegal, A.; Peris, P.; Rodés, J. Severity of cholestasis and advanced histological stage but not menopausal status are the major risk factors for osteoporosis in primary biliary cirrhosis. J. Hepatol. 2005, 42, 573-577. [CrossRef]

21. Angulo, P.; Grandison, G.A.; Fong, D.G.; Keach, J.C.; Lindor, K.D.; Bjornsson, E.; Koch, A. Bone Disease in Patients with Primary Sclerosing Cholangitis. Gastroenterology 2011, 140, 180-188. [CrossRef] [PubMed]

22. Solaymani-Dodaran, M.; Card, T.R.; Aithal, G.P.; West, J. Fracture Risk in People with Primary Biliary Cirrhosis: A PopulationBased Cohort Study. Gastroenterology 2006, 131, 1752-1757. [CrossRef] [PubMed]

23. Guañabens, N.; Cerdá, D.; Monegal, A.; Pons, F.; Caballería, L.; Peris, P.; Parés, A. Low Bone Mass and Severity of Cholestasis Affect Fracture Risk in Patients with Primary Biliary Cirrhosis. Gastroenterology 2010, 138, 2348-2356. [CrossRef] [PubMed]

24. Orsini, L.G.S.; Pinheiro, M.M.; Castro, C.H.M.; Silva, A.E.B.; Szejnfeld, V.L. Bone Mineral Density Measurements, Bone Markers and Serum Vitamin D Concentrations in Men with Chronic Non-Cirrhotic Untreated Hepatitis C. PLoS ONE 2013, 8, e81652. [CrossRef] [PubMed]

25. Lai, J.C.; Shoback, D.M.; Zipperstein, J.; Lizaola, B.; Tseng, S.; Terrault, N.A. Bone Mineral Density, Bone Turnover, and Systemic Inflammation in Non-cirrhotics with Chronic Hepatitis C. Dig. Dis. Sci. 2015, 60, 1813-1819. [CrossRef]

26. Huang, Z.; Wei, H.; Cheng, C.; Yang, S.; Wang, J.; Liu, X. Low bone mineral density in chronic hepatitis B virus infection: A case-control study. Pak. J. Med. Sci. 2017, 33, 457-461. [CrossRef]

27. Wei, M.T.; Le, A.K.; Chang, M.S.; Hsu, H.; Nguyen, P.; Zhang, J.Q.; Wong, C.; Wong, C.; Cheung, R.; Nguyen, M.H. Antiviral therapy and the development of osteopenia/osteoporosis among Asians with chronic hepatitis B. J. Med. Virol. 2019, 91, 1288-1294. [CrossRef]

28. Schiefke, I.; Fach, A.; Wiedmann, M.; Aretin, A.V.; Schenker, E.; Borte, G.; Wiese, M.; Moessner, J. Reduced bone mineral density and altered bone turnover markers in patients with non-cirrhotic chronic hepatitis B or C infection. World J. Gastroenterol. 2005, 11, 1843-1847. [CrossRef]

29. Hansen, A.-B.E.; Omland, L.H.; Krarup, H.; Obel, N. Fracture risk in hepatitis C virus infected persons: Results from the DANVIR cohort study. J. Hepatol. 2014, 61, 15-21. [CrossRef]

30. Goubraim, R.; Kabbaj, N.; Salihoun, M.; Chaoui, Z.; Nya, M.; Amrani, N. Metabolic Bone Disease in Viral Cirrhosis: A Prospective Study. ISRN Hepatol. 2013, 2013, 276563. [CrossRef]

31. Sokhi, R.P.; Anantharaju, A.; Kondaveeti, R.; Creech, S.D.; Islam, K.K.; Van Thiel, D.H. Bone mineral density among cirrhotic patients awaiting liver transplantation. Liver Transplant. 2004, 10, 648-653. [CrossRef] [PubMed]

32. Zheng, J.-P.; Miao, H.-X.; Zheng, S.-W.; Liu, W.-L.; Chen, C.-Q.; Zhong, H.-B.; Li, S.-F.; Fang, Y.-P.; Sun, C.-H. Risk factors for osteoporosis in liver cirrhosis patients measured by transient elastography. Medicine 2018, 97, e10645. [CrossRef] [PubMed]

33. Monegal, A.; Navasa, M.; Guañabens, N.; Peris, P.; Pons, F.; De Osaba, M.J.M.; Rimola, A.; Rodés, J.; Muñoz-Gómez, J. Osteoporosis and Bone Mineral Metabolism Disorders in Cirrhotic Patients Referred for Orthotopic Liver Transplantation. Calcif. Tissue Int. 1997, 60, 148-154. [CrossRef] [PubMed]

34. Monegal, A.; Navasa, M.; Guañabens, N.; Peris, P.; Pons, F.; De Osaba, M.J.M.; Ordi, J.; Rimola, A.; Rodés, J.; Muñoz-Gómez, J. Bone Disease after Liver Transplantation: A Long-Term Prospective Study of Bone Mass Changes, Hormonal Status and Histomorphometric Characteristics. Osteoporos. Int. 2001, 12, 484-492. [CrossRef] [PubMed]

35. Guichelaar, M.M.J.; Kendall, R.; Malinchoc, M.; Hay, J.E. Bone mineral density before and after OLT: Long-term follow-up and predictive factors. Liver Transplant. 2006, 12, 1390-1402. [CrossRef]

36. Li, M.; Xu, Y.; Xu, M.; Ma, L.; Wang, T.; Liu, Y.; Dai, M.; Chen, Y.; Lu, J.; Liu, J.; et al. Association between Nonalcoholic Fatty Liver Disease (NAFLD) and Osteoporotic Fracture in Middle-Aged and Elderly Chinese. J. Clin. Endocrinol. Metab. 2012, 97, $2033-2038$. [CrossRef]

37. Purnak, T.; Beyazit, Y.; Ozaslan, E.; Efe, C.; Hayretci, M.; Ozaslan, A.P.E. The evaluation of bone mineral density in patients with nonalcoholic fatty liver disease. Wien. Klin. Wochenschr. 2012, 124, 526-531. [CrossRef] [PubMed]

38. Kim, G.; Kim, K.J.; Rhee, Y.; Lim, S.-K. Significant liver fibrosis assessed using liver transient elastography is independently associated with low bone mineral density in patients with non-alcoholic fatty liver disease. PLoS ONE 2017, 12, e0182202. [CrossRef] [PubMed] 
39. Ahn, S.H.; Seo, D.H.; Kim, S.H.; Nam, M.-S.; Hong, S. The relationship between fatty liver index and bone mineral density in Koreans: KNHANES 2010-2011. Osteoporos. Int. 2017, 29, 181-190. [CrossRef]

40. Malik, P.; Gasser, R.W.; Kemmler, G.; Moncayo, R.; Finkenstedt, G.; Kurz, M.; Fleischhacker, W.W. Low Bone Mineral Density and Impaired Bone Metabolism in Young Alcoholic Patients without Liver Cirrhosis: A Cross-Sectional Study. Alcohol. Clin. Exp. Res. 2009, 33, 375-381. [CrossRef] [PubMed]

41. Peris, P.; Guañabens, N.; Parés, A.; Pons, F.; Del Rio, L.; Monegal, A.; Surís, X.; Caballería, J.; Rodés, J.; Muñoz-Gómez, J. Vertebral fractures and osteopenia in chronic alcoholic patients. Calcif. Tissue Int. 1995, 57, 111-114. [CrossRef]

42. Peris, P.; Pares, A.; Guanabens, N.; Del Rio, L.; Pons, F.; De Osaba, M.J.M.; Monegal, A.; Caballería, J.; Rodés, J.; Muñoz-Gómez, J. Bone mass improves in alcoholics after 2 years of abstinence. J. Bone Miner. Res. 1994, 9, 1607-1612. [CrossRef]

43. Sinigaglia, L.; Fargion, S.; Fracanzani, A.L.; Binelli, L.; Battafarano, N.; Varenna, M.; Piperno, A.; Fiorelli, G. Bone and joint involvement in genetic hemochromatosis: Role of cirrhosis and iron overload. J. Rheumatol. 1997, 24, 1809-1813.

44. Guggenbuhl, P.; Deugnier, Y.; Boisdet, J.F.; Rolland, Y.; Perdriger, A.; Pawlotsky, Y.; Chalès, G. Bone mineral density in men with genetic hemochromatosis and HFE gene mutation. Osteoporos. Int. 2005, 16, 1809-1814. [CrossRef] [PubMed]

45. Valenti, L.; Varenna, M.; Fracanzani, A.L.; Rossi, V.; Fargion, S.; Sinigaglia, L. Association between iron overload and osteoporosis in patients with hereditary hemochromatosis. Osteoporos. Int. 2009, 20, 549-555. [CrossRef]

46. Weiss, K.H.; Van De Moortele, M.; Gotthardt, D.N.; Pfeiffenberger, J.; Seessle, J.; Ullrich, E.; Gielen, E.; Borghs, H.; Adriaens, E.; Stremmel, W.; et al. Bone demineralisation in a large cohort of Wilson disease patients. J. Inherit. Metab. Dis. 2015, 38, 949-956. [CrossRef] [PubMed]

47. Quemeneur, A.-S.; Trocello, J.-M.; Ea, H.-K.; Ostertag, A.; Leyendecker, A.; Duclos-Vallee, J.-C.; De Vernejoul, M.-C.; Woimant, F.; Lioté, F. Bone status and fractures in 85 adults with Wilson's disease. Osteoporos. Int. 2014, 25, 2573-2580. [CrossRef]

48. Danford, C.J.; Trivedi, H.D.; Bonder, A. Bone Health in Patients with Liver Diseases. J. Clin. Densitom. 2020, $23,212-222$. [CrossRef] [PubMed]

49. Danford, C.J.; Trivedi, H.D.; Papamichael, K.; Tapper, E.B.; Bonder, A. Osteoporosis in primary biliary cholangitis. World J. Gastroenterol. 2018, 24, 3513-3520. [CrossRef] [PubMed]

50. Raggatt, L.J.; Partridge, N.C. Cellular and Molecular Mechanisms of Bone Remodeling. J. Biol. Chem. 2010, 285, 25103-25108. [CrossRef] [PubMed]

51. Boyce, B.F.; Xing, L. Functions of RANKL/RANK/OPG in bone modeling and remodeling. Arch. Biochem. Biophys. 2008, 473, 139-146. [CrossRef]

52. Ono, T.; Hayashi, M.; Sasaki, F.; Nakashima, T. RANKL biology: Bone metabolism, the immune system, and beyond. Inflamm. Regen. 2020, 40, 1-16. [CrossRef]

53. Santos, L.A.A.; Romeiro, F.G. Diagnosis and Management of Cirrhosis-Related Osteoporosis. BioMed Res. Int. 2016, $2016,1423462$. [CrossRef]

54. Moschen, A.R.; Kaser, A.; Stadlmann, S.; Millonig, G.; Kaser, S.; Mühllechner, P.; Habior, A.; Graziadei, I.; Vogel, W.; Tilg, H The RANKL/OPG system and bone mineral density in patients with chronic liver disease. J. Hepatol. 2005, 43, 973-983. [CrossRef] [PubMed]

55. Ruiz-Gaspà, S.; Martinez-Ferrer, A.; Guañabens, N.; Dubreuil, M.; Peris, P.; Enjuanes, A.; De Osaba, M.J.M.; Alvarez, L.; Monegal, A.; Combalia, A.; et al. Effects of bilirubin and sera from jaundiced patients on osteoblasts: Contribution to the development of osteoporosis in liver diseases. Hepatology 2011, 54, 2104-2113. [CrossRef]

56. Blaschke, M.; Koepp, R.; Cortis, J.; Komrakova, M.; Schieker, M.; Hempel, U.; Siggelkow, H. IL-6, IL-1 $\beta$, and TNF- $\alpha$ only in combination influence the osteoporotic phenotype in Crohn's patients via bone formation and bone resorption. Adv. Clin. Exp. Med. 2018, 27, 45-56. [CrossRef]

57. Lorenzo, J.; Horowitz, M.; Choi, Y. Osteoimmunology: Interactions of the Bone and Immune System. Endocr. Rev. 2008, 29, 403-440. [CrossRef]

58. Wu, Q.; Zhou, X.; Huang, D.; Ji, Y.; Kang, F. IL-6 Enhances Osteocyte-Mediated Osteoclastogenesis by Promoting JAK2 and RANKL Activity In Vitro. Cell. Physiol. Biochem. 2017, 41, 1360-1369. [CrossRef]

59. Nakchbandi, I.A.; Mitnick, M.A.; Lang, R.; Gundberg, C.; Kinder, B.; Insogna, K. Circulating Levels of Interleukin-6 Soluble Receptor Predict Rates of Bone Loss in Patients with Primary Hyperparathyroidism. J. Clin. Endocrinol. Metab. 2002, 87, $4946-4951$. [CrossRef] [PubMed]

60. Li, X.; Zhou, Z.-Y.; Zhang, Y.-Y.; Yang, H.-L. IL-6 Contributes to the Defective Osteogenesis of Bone Marrow Stromal Cells from the Vertebral Body of the Glucocorticoid-Induced Osteoporotic Mouse. PLoS ONE 2016, 11, e0154677. [CrossRef] [PubMed]

61. Axmann, R.; Böhm, C.; Krönke, G.; Zwerina, J.; Smolen, J.; Schett, G. Inhibition of interleukin-6 receptor directly blocks osteoclast formation in vitro and in vivo. Arthritis Rheum. 2009, 60, 2747-2756. [CrossRef]

62. Norris, C.A.; He, M.; Kang, L.-I.; Ding, M.Q.; Radder, J.E.; Haynes, M.M.; Yang, Y.; Paranjpe, S.; Bowen, W.C.; Orr, A.; et al Synthesis of IL-6 by Hepatocytes Is a Normal Response to Common Hepatic Stimuli. PLoS ONE 2014, 9, e96053. [CrossRef] [PubMed]

63. Shimada, M.; Matsumata, T.; Taketomi, A.; Shirabe, K.; Yamamoto, K.; Takenaka, K.; Sugimachi, K. The role of interleukin-6, interleukin-16, tumor necrosis factor-alpha and endotoxin in hepatic resection. Hepatogastroenterology 1995, 42, 691-697. [PubMed]

64. Guarino, M.; Loperto, I.; Camera, S.; Cossiga, V.; Di Somma, C.; Colao, A.; Caporaso, N.; Morisco, F. Osteoporosis across chronic liver disease. Osteoporos. Int. 2016, 27, 1967-1977. [CrossRef] [PubMed] 
65. Handzlik-Orlik, G.; Holecki, M.; Wilczyński, K.; Duława, J. Osteoporosis in liver disease: Pathogenesis and management. Ther. Adv. Endocrinol. Metab. 2016, 7, 128-135. [CrossRef] [PubMed]

66. Zhao, B.; Grimes, S.N.; Li, S.; Hu, X.; Ivashkiv, L.B. TNF-induced osteoclastogenesis and inflammatory bone resorption are inhibited by transcription factor RBP-J. J. Exp. Med. 2012, 209, 319-334. [CrossRef]

67. Boyce, B.E.; Li, P.; Yao, Z.; Zhang, Q.; Badell, I.R.; Schwarz, E.M.; O’Keefe, R.J.; Xing, L. TNF.ALPHA. and pathologic bone resorption. Keio J. Med. 2005, 54, 127-131. [CrossRef] [PubMed]

68. González-Calvin, J.L.; Gallego-Rojo, F.; Fernández-Pérez, R.; Casado-Caballero, F.; Ruiz-Escolano, E.; Olivares, E.G. Osteoporosis, Mineral Metabolism, and Serum Soluble Tumor Necrosis Factor Receptor p55 in Viral Cirrhosis. J. Clin. Endocrinol. Metab. 2004, 89, 4325-4330. [CrossRef]

69. Filip, R.; Radzki, R.P.; Bieńko, M. Novel insights into the relationship between nonalcoholic fatty liver disease and osteoporosis. Clin. Interv. Aging 2018, 13, 1879-1891. [CrossRef]

70. Manco, M.; Marcellini, M.; Giannone, G.; Nobili, V. Correlation of Serum TNF- $\alpha$ Levels and Histologic Liver Injury Scores in Pediatric Nonalcoholic Fatty Liver Disease. Am. J. Clin. Pathol. 2007, 127, 954-960. [CrossRef]

71. McCaughan, G.; Feller, R. Osteoporosis in Chronic Liver Disease: Pathogenesis, Risk Factors, and Management. Dig. Dis. 1994, 12, 223-231. [CrossRef]

72. Koshihara, Y.; Hoshi, K.; Okawara, R.; Ishibashi, H.; Yamamoto, S. Vitamin K stimulates osteoblastogenesis and inhibits osteoclastogenesis in human bone marrow cell culture. J. Endocrinol. 2003, 176, 339-348. [CrossRef] [PubMed]

73. Hiruma, Y.; Nakahama, K.-I.; Fujita, H.; Morita, I. Vitamin K2 and geranylgeraniol, its side chain component, inhibited osteoclast formation in a different manner. Biochem. Biophys. Res. Commun. 2004, 314, 24-30. [CrossRef] [PubMed]

74. Cockayne, S.; Adamson, J.; Lanham-New, S.; Shearer, M.J.; Gilbody, S.; Torgerson, D.J. Vitamin K and the prevention of fractures: Systematic review and meta-analysis of randomized controlled trials. Arch. Intern. Med. 2006, 166, 1256-1261. [CrossRef]

75. Kowdley, K.V.; Emond, M.J.; Sadowski, J.A.; Kaplan, M.M. Plasma vitamin K1 level is decreased in primary biliary cirrhosis. Am. J. Gastroenterol. 1997, 92, 2059-2061. [PubMed]

76. Nishiguchi, S.; Shimoi, S.; Kurooka, H.; Tamori, A.; Habu, D.; Takeda, T.; Ochi, H. Randomized pilot trial of vitamin K2 for bone loss in patients with primary biliary cirrhosis. J. Hepatol. 2001, 35, 543-545. [CrossRef]

77. Ruiz-Gaspà, S.; Dubreuil, M.; Guañabens, N.; Combalia, A.; Peris, P.; Monegal, A.; Parés, A. Ursodeoxycholic acid decreases bilirubin-induced osteoblast apoptosis. Eur. J. Clin. Investig. 2014, 44, 1206-1214. [CrossRef] [PubMed]

78. Ukon, Y.; Makino, T.; Kodama, J.; Tsukazaki, H.; Tateiwa, D.; Yoshikawa, H.; Kaito, T. Molecular-Based Treatment Strategies for Osteoporosis: A Literature Review. Int. J. Mol. Sci. 2019, 20, 2557. [CrossRef]

79. Delgado-Calle, J.; Sato, A.Y.; Bellido, T. Role and mechanism of action of sclerostin in bone. Bone 2017, 96, 29-37. [CrossRef] [PubMed]

80. Reid, I.R. Targeting Sclerostin in Postmenopausal Osteoporosis: Focus on Romosozumab and Blosozumab. BioDrugs 2017, 31, 289-297. [CrossRef]

81. Li, X.; Zhang, Y.; Kang, H.; Liu, W.; Liu, P.; Zhang, J.; Harris, S.E.; Wu, D. Sclerostin Binds to LRP5/6 and Antagonizes Canonical Wnt Signaling. J. Biol. Chem. 2005, 280, 19883-19887. [CrossRef] [PubMed]

82. Guañabens, N.; Gifre, L.; Miquel, R.; Peris, P.; Monegal, A.; Dubrueil, M.; Arias, A.; Parés, A.; Ruiz-Gaspà, S. Sclerostin Expression in Bile Ducts of Patients with Chronic Cholestasis May Influence the Bone Disease in Primary Biliary Cirrhosis. J. Bone Miner. Res. 2016, 31, 1725-1733. [CrossRef] [PubMed]

83. Rhee, Y.; Kim, W.J.; Han, K.J.; Kil Lim, S.; Kim, S.H. Effect of liver dysfunction on circulating sclerostin. J. Bone Miner. Metab. 2013, 32, 545-549. [CrossRef] [PubMed]

84. Locatelli, V.; Bianchi, V.E. Effect of GH/IGF-1 on Bone Metabolism and Osteoporsosis. Int. J. Endocrinol. 2014, 2014, 235060 [CrossRef] [PubMed]

85. Kobayashi, Y.; Uehara, S.; Udagawa, N.; Takahashi, N. Regulation of bone metabolism by Wnt signals. J. Biochem. 2016, 159, 387-392. [CrossRef]

86. Guerra-Menéndez, L.; Sádaba, M.C.; Puche, J.E.; Lavandera, J.L.; de Castro, L.F.; de Gortázar, A.R.; Castilla-Cortázar, I. IGFI increases markers of osteoblastic activity and reduces bone resorption via osteoprotegerin and RANK-ligand. J. Trans. Med. 2013, 11, 271. [CrossRef] [PubMed]

87. De La Garza, R.G.; Morales-Garza, L.A.; Martin-Estal, I.; Castilla-Cortazar, I. Insulin-Like Growth Factor-1 Deficiency and Cirrhosis Establishment. J. Clin. Med. Res. 2017, 9, 233-247. [CrossRef]

88. Thrailkill, K.M.; Lumpkin, C.K.; Bunn, R.C.; Kemp, S.F.; Fowlkes, J.L. Is insulin an anabolic agent in bone? Dissecting the diabetic bone for clues. Am. J. Physiol. Metab. 2005, 289, E735-E745. [CrossRef] [PubMed]

89. Neong, S.F.; Billington, E.O.; Congly, S.E. Sexual Dysfunction and Sex Hormone Abnormalities in Patients with Cirrhosis: Review of Pathogenesis and Management. Hepatology 2018, 69, 2683-2695. [CrossRef] [PubMed]

90. Golds, G.; Houdek, D.; Arnason, T. Male Hypogonadism and Osteoporosis: The Effects, Clinical Consequences, and Treatment of Testosterone Deficiency in Bone Health. Int. J. Endocrinol. 2017, 2017, 4602129. [CrossRef]

91. Sarkar, M.; Lai, J.C.; Sawinski, D.; Zeigler, T.E.; Cedars, M.; Forde, K.A. Sex hormone levels by presence and severity of cirrhosis in women with chronic hepatitis C virus infection. J. Viral Hepat. 2018, 26, 258-262. [CrossRef] [PubMed]

92. Nakchbandi, I.A. Osteoporosis and fractures in liver disease: Relevance, pathogenesis and therapeutic implications. World J. Gastroenterol. 2014, 20, 9427-9438. 
93. Zumoff, B.; Fishman, J.; Gallagher, T.F.; Hellman, L. Estradiol metabolism in cirrhosis. J. Clin. Investig. 1968, 47, 20-25. [CrossRef]

94. Cruz-Jentoft, A.J.; Sayer, A.A. Sarcopenia. Lancet 2019, 393, 2636-2646. [CrossRef]

95. Cruz-Jentoft, A.J.; Bahat, G.; Bauer, J.; Boirie, Y.; Bruyère, O.; Cederholm, T.; Cooper, C.; Landi, F.; Rolland, Y.; Sayer, A.A.; et al. Sarcopenia: Revised European consensus on definition and diagnosis. Age Ageing 2019, 48, 16-31. [CrossRef] [PubMed]

96. Chen, L.-K.; Woo, J.; Assantachai, P.; Auyeung, T.-W.; Chou, M.-Y.; Iijima, K.; Jang, H.C.; Kang, L.; Kim, M.; Kim, S.; et al. Asian Working Group for Sarcopenia: 2019 Consensus Update on Sarcopenia Diagnosis and Treatment. J. Am. Med. Dir. Assoc. 2020, 21, 300-307.e2. [CrossRef]

97. Cruz-Jentoft, A.J.; Baeyens, J.P.; Bauer, J.M.; Boirie, Y.; Cederholm, T.; Landi, F.; Martin, F.C.; Michel, J.-P.; Rolland, Y.; Schneider, S.M.; et al. Sarcopenia: European consensus on definition and diagnosis: Report of the European Working Group on Sarcopenia in Older People. Age Ageing 2010, 39, 412-423. [CrossRef] [PubMed]

98. Clark, B.C.; Manini, T.M. Sarcopenia =/= dynapenia. J. Gerontol. Ser. A Biol. Sci. Med. Sci. 2008, 63, 829-834. [CrossRef] [PubMed]

99. Lee, Y.-H.; Jung, K.S.; Kim, S.U.; Yoon, H.-J.; Yun, Y.J.; Lee, B.-W.; Kang, E.S.; Han, K.-H.; Lee, H.C.; Cha, B.-S. Sarcopaenia is associated with NAFLD independently of obesity and insulin resistance: Nationwide surveys (KNHANES 2008-2011). J. Hepatol. 2015, 63, 486-493. [CrossRef] [PubMed]

100. Hong, H.C.; Hwang, S.Y.; Choi, H.Y.; Yoo, H.J.; Seo, J.A.; Kim, S.G.; Kim, N.H.; Baik, S.H.; Choi, D.S.; Choi, K.M. Relationship between sarcopenia and nonalcoholic fatty liver disease: The Korean Sarcopenic Obesity Study. Hepatology 2014, 59, 1772-1778. [CrossRef] [PubMed]

101. Carias, S.; Castellanos, A.L.; Vilchez, V.; Nair, R.; Cruz, A.C.D.; Watkins, J.; Barrett, T.; Trushar, P.; Esser, K.; Gedaly, R. Nonalcoholic steatohepatitis is strongly associated with sarcopenic obesity in patients with cirrhosis undergoing liver transplant evaluation. J. Gastroenterol. Hepatol. 2016, 31, 628-633. [CrossRef] [PubMed]

102. Koo, B.K.; Kim, D.; Joo, S.K.; Kim, J.H.; Chang, M.S.; Kim, B.G.; Lee, K.L.; Kim, W. Sarcopenia is an independent risk factor for non-alcoholic steatohepatitis and significant fibrosis. J. Hepatol. 2017, 66, 123-131. [CrossRef] [PubMed]

103. Gan, D.; Wang, L.; Jia, M.; Ru, Y.; Ma, Y.; Zheng, W.; Zhao, X.; Yang, F.; Wang, T.; Mu, Y.; et al. Low muscle mass and low muscle strength associate with nonalcoholic fatty liver disease. Clin. Nutr. 2020, 39, 1124-1130. [CrossRef] [PubMed]

104. Kim, G.; Lee, S.; Lee, Y.; Jun, J.E.; Ahn, J.; Bae, J.C.; Jin, S.; Hur, K.Y.; Jee, J.H.; Lee, M.; et al. Relationship Between Relative Skeletal Muscle Mass and Nonalcoholic Fatty Liver Disease: A 7-Year Longitudinal Study. Hepatology 2018, 68, 1755-1768. [CrossRef] [PubMed]

105. Tandon, P.; Ney, M.; Irwin, I.; Ma, M.M.; Gramlich, L.; Bain, V.G.; Esfandiari, N.; Baracos, V.; Montano-Loza, A.J.; Myers, R.P. Severe muscle depletion in patients on the liver transplant wait list: Its prevalence and independent prognostic value. Liver Transplant. 2012, 18, 1209-1216. [CrossRef] [PubMed]

106. Montano-Loza, A.J.; Meza-Junco, J.; Prado, C.M.; Lieffers, J.R.; Baracos, V.E.; Bain, V.G.; Sawyer, M.B. Muscle Wasting Is Associated with Mortality in Patients with Cirrhosis. Clin. Gastroenterol. Hepatol. 2012, 10, 166-173.e1. [CrossRef]

107. Merli, M.; Giusto, M.; Lucidi, C.; Giannelli, V.; Pentassuglio, I.; Di Gregorio, V.; Lattanzi, B.; Riggio, O. Muscle depletion increases the risk of overt and minimal hepatic encephalopathy: Results of a prospective study. Metab. Brain Dis. 2013, 28, 281-284. [CrossRef]

108. Kim, T.Y.; Kim, M.Y.; Sohn, J.H.; Kim, S.M.; Ryu, J.A.; Lim, S.; Kim, Y. Sarcopenia as a Useful Predictor for Long-Term Mortality in Cirrhotic Patients with Ascites. J. Korean Med. Sci. 2014, 29, 1253-1259. [CrossRef] [PubMed]

109. Durand, F.; Buyse, S.; Francoz, C.; Laouénan, C.; Bruno, O.; Belghiti, J.; Moreau, R.; Vilgrain, V.; Valla, D. Prognostic value of muscle atrophy in cirrhosis using psoas muscle thickness on computed tomography. J. Hepatol. 2014, 60, 1151-1157. [CrossRef] [PubMed]

110. Hanai, T.; Shiraki, M.; Nishimura, K.; Ohnishi, S.; Imai, K.; Suetsugu, A.; Takai, K.; Shimizu, M.; Moriwaki, H. Sarcopenia impairs prognosis of patients with liver cirrhosis. Nutrient 2015, 31, 193-199. [CrossRef] [PubMed]

111. Montano-Loza, A.J.; Duarte-Rojo, A.; Meza-Junco, J.; Baracos, V.E.; Sawyer, M.B.; Pang, J.X.Q.; Beaumont, C.; Esfandiari, N.; Myers, R.P. Inclusion of Sarcopenia Within MELD (MELD-Sarcopenia) and the Prediction of Mortality in Patients with Cirrhosis. Clin. Transl. Gastroenterol. 2015, 6, e102. [CrossRef]

112. Hanai, T.; Shiraki, M.; Ohnishi, S.; Miyazaki, T.; Ideta, T.; Kochi, T.; Imai, K.; Suetsugu, A.; Takai, K.; Moriwaki, H.; et al. Rapid skeletal muscle wasting predicts worse survival in patients with liver cirrhosis. Hepatol. Res. 2016, 46, 743-751. [CrossRef] [PubMed]

113. Nardelli, S.; Lattanzi, B.; Torrisi, S.; Greco, F.; Farcomeni, A.; Gioia, S.; Merli, M.; Riggio, O. Sarcopenia Is Risk Factor for Development of Hepatic Encephalopathy after Transjugular Intrahepatic Portosystemic Shunt Placement. Clin. Gastroenterol. Hepatol. 2017, 15, 934-936. [CrossRef] [PubMed]

114. Kang, S.H.; Jeong, W.K.; Baik, S.K.; Cha, S.H.; Kim, M.Y. Impact of sarcopenia on prognostic value of cirrhosis: Going beyond the hepatic venous pressure gradient and MELD score. J. Cachex-Sarcopenia Muscle 2018, 9, 860-870. [CrossRef]

115. Englesbe, M.J.; Patel, S.P.; He, K.; Lynch, R.J.; Schaubel, D.E.; Harbaugh, C.; Holcombe, S.A.; Wang, S.C.; Segev, D.L.; Sonnenday, C.J. Sarcopenia and Mortality after Liver Transplantation. J. Am. Coll. Surg. 2010, 211, 271-278. [CrossRef] [PubMed]

116. Kaido, T.; Ogawa, K.; Fujimoto, Y.; Ogura, Y.; Hata, K.; Ito, T.; Tomiyama, K.; Yagi, S.; Mori, A.; Uemoto, S. Impact of Sarcopenia on Survival in Patients Undergoing Living Donor Liver Transplantation. Arab. Archaeol. Epigr. 2013, 13, 1549-1556. [CrossRef] 
117. Krell, R.W.; Kaul, D.R.; Martin, A.R.; Englesbe, M.J.; Sonnenday, C.J.; Cai, S.; Malani, P.N. Association between sarcopenia and the risk of serious infection among adults undergoing liver transplantation. Liver Transplant. 2013, 19, 1396-1402. [CrossRef]

118. Tsien, C.; Garber, A.; Narayanan, A.; Shah, S.N.; Barnes, D.; Eghtesad, B.; Fung, J.; McCullough, A.J.; Dasarathy, S. Post-liver transplantation sarcopenia in cirrhosis: A prospective evaluation. J. Gastroenterol. Hepatol. 2014, 29, 1250-1257. [CrossRef] [PubMed]

119. Montano-Loza, A.J.; Meza-Junco, J.; Baracos, V.E.; Prado, C.M.M.; Ma, M.; Meeberg, G.; Beaumont, C.; Tandon, P.; Esfandiari, N.; Sawyer, M.B.; et al. Severe muscle depletion predicts postoperative length of stay but is not associated with survival after liver transplantation. Liver Transplant. 2014, 20, 640-648. [CrossRef]

120. Masuda, T.; Shirabe, K.; Ikegami, T.; Harimoto, N.; Yoshizumi, T.; Soejima, Y.; Uchiyama, H.; Ikeda, T.; Baba, H.; Maehara, Y. Sarcopenia is a prognostic factor in living donor liver transplantation. Liver Transplant. 2014, 20, 401-407. [CrossRef]

121. Hamaguchi, Y.; Kaido, T.; Okumura, S.; Fujimoto, Y.; Ogawa, K.; Mori, A.; Hammad, A.; Tamai, Y.; Inagaki, N.; Uemoto, S. Impact of quality as well as quantity of skeletal muscle on outcomes after liver transplantation. Liver Transplant. 2014, 20, 1413-1419. [CrossRef] [PubMed]

122. Kalafateli, M.; Mantzoukis, K.; Yau, Y.C.; Mohammad, A.O.; Arora, S.; Rodrigues, S.; De Vos, M.; Papadimitriou, K.; Thorburn, D.; O'Beirne, J.; et al. Malnutrition and sarcopenia predict post-liver transplantation outcomes independently of the Model for End-stage Liver Disease score. J. Cachex-Sarcopenia Muscle 2017, 8, 113-121. [CrossRef]

123. Meza-Junco, J.; Montano-Loza, A.J.; Baracos, V.E.; Prado, C.M.; Bain, V.G.; Beaumont, C.; Esfandiari, N.; Lieffers, J.R.; Sawyer, M.B. Sarcopenia as a Prognostic Index of Nutritional Status in Concurrent Cirrhosis and Hepatocellular Carcinoma. J. Clin. Gastroenterol. 2013, 47, 861-870. [CrossRef]

124. Harimoto, N.; Shirabe, K.; Yamashita, Y.-I.; Ikegami, T.; Yoshizumi, T.; Soejima, Y.; Ikeda, T.; Maehara, Y.; Nishie, A.; Yamanaka, T. Sarcopenia as a predictor of prognosis in patients following hepatectomy for hepatocellular carcinoma. BJS 2013, 100, 1523-1530. [CrossRef] [PubMed]

125. Fujiwara, N.; Nakagawa, H.; Kudo, Y.; Tateishi, R.; Taguri, M.; Watadani, T.; Nakagomi, R.; Kondo, M.; Nakatsuka, T.; Minami, T.; et al. Sarcopenia, intramuscular fat deposition, and visceral adiposity independently predict the outcomes of hepatocellular carcinoma. J. Hepatol. 2015, 63, 131-140. [CrossRef] [PubMed]

126. Drummond, M.J.; Dreyer, H.C.; Fry, C.S.; Glynn, E.L.; Rasmussen, B.B. Nutritional and contractile regulation of human skeletal muscle protein synthesis and mTORC1 signaling. J. Appl. Physiol. 2009, 106, 1374-1384. [CrossRef] [PubMed]

127. Nishikawa, H.; Enomoto, H.; Ishii, A.; Iwata, Y.; Miyamoto, Y.; Ishii, N.; Yuri, Y.; Hasegawa, K.; Nakano, C.; Nishimura, T.; et al. Elevated serum myostatin level is associated with worse survival in patients with liver cirrhosis. J. Cachex-Sarcopenia Muscle 2017, 8, 915-925. [CrossRef]

128. Han, H.; Zhou, X.; Mitch, W.E.; Goldberg, A.L. Myostatin/activin pathway antagonism: Molecular basis and therapeutic potential. Int. J. Biochem. Cell Biol. 2013, 45, 2333-2347. [CrossRef]

129. Garikipati, D.K.; Rodgers, B.D. Myostatin inhibits myosatellite cell proliferation and consequently activates differentiation: Evidence for endocrine-regulated transcript processing. J. Endocrinol. 2012, 215, 177-187. [CrossRef] [PubMed]

130. Polyzos, S.A.; Margioris, A.N. Sarcopenic obesity. Hormones 2018, 17, 321-331. [CrossRef]

131. Kalyani, R.R.; Corriere, M.; Ferrucci, L. Age-related and disease-related muscle loss: The effect of diabetes, obesity, and other diseases. Lancet Diabetes Endocrinol. 2014, 2, 819-829. [CrossRef]

132. Vitale, G.; Cesari, M.; Mari, D. Aging of the endocrine system and its potential impact on sarcopenia. Eur. J. Intern. Med. 2016, 35, 10-15. [CrossRef]

133. Wang, X.; Hu, Z.; Hu, J.; Du, J.; Mitch, W.E. Insulin Resistance Accelerates Muscle Protein Degradation: Activation of the Ubiquitin-Proteasome Pathway by Defects in Muscle Cell Signaling. Endocrinology 2006, 147, 4160-4168. [CrossRef]

134. Schiaffino, S.; Mammucari, C. Regulation of skeletal muscle growth by the IGF1-Akt/PKB pathway: Insights from genetic models. Skelet. Muscle 2011, 1, 4. [CrossRef]

135. Cabrera, D.; Ruiz, A.; Cabello-Verrugio, C.; Brandan, E.; Estrada, L.; Pizarro, M.; Solis, N.; Torres, J.; Barrera, F.; Arrese, M. Diet-Induced Nonalcoholic Fatty Liver Disease Is Associated with Sarcopenia and Decreased Serum Insulin-Like Growth Factor-1. Dig. Dis. Sci. 2016, 61, 3190-3198. [CrossRef] [PubMed]

136. Cabrera, D.; Cabello-Verrugio, C.; Solís, N.; Martín, D.S.; Cofré, C.; Pizarro, M.; Arab, J.P.; Abrigo, J.; Campos, F.; Irigoyen, B.; et al. Somatotropic Axis Dysfunction in Non-Alcoholic Fatty Liver Disease: Beneficial Hepatic and Systemic Effects of Hormone Supplementation. Int. J. Mol. Sci. 2018, 19, 1339. [CrossRef]

137. Serrano, A.L.; Baeza-Raja, B.; Perdiguero, E.; Jardí, M.; Muñoz-Cánoves, P. Interleukin-6 Is an Essential Regulator of Satellite Cell-Mediated Skeletal Muscle Hypertrophy. Cell Metab. 2008, 7, 33-44. [CrossRef]

138. Haddad, F.; Zaldivar, F.; Cooper, D.M.; Adams, G.R. IL-6-induced skeletal muscle atrophy. J. Appl. Physiol. 2005, 98, 911-917. [CrossRef]

139. Steinberg, G.R.; Michell, B.J.; Van Denderen, B.J.; Watt, M.J.; Carey, A.L.; Fam, B.C.; Andrikopoulos, S.; Proietto, J.; Görgün, C.Z.; Carling, D.; et al. Tumor necrosis factor $\alpha$-induced skeletal muscle insulin resistance involves suppression of AMP-kinase signaling. Cell Metab. 2006, 4, 465-474. [CrossRef] [PubMed]

140. Yaribeygi, H.; Farrokhi, F.R.; Butler, A.E.; Sahebkar, A. Insulin resistance: Review of the underlying molecular mechanisms. J. Cell. Physiol. 2019, 234, 8152-8161. [CrossRef] [PubMed]

141. Saxena, N.K.; Anania, F.A. Adipocytokines and hepatic fibrosis. Trends Endocrinol. Metab. 2015, 26, 153-161. [CrossRef] [PubMed] 
142. Chen, M.B.; McAinch, A.J.; Macaulay, S.L.; Castelli, L.A.; O’Brien, P.E.; Dixon, J.B.; Cameron-Smith, D.; Kemp, B.E.; Steinberg, G.R. Impaired activation of AMP-kinase and fatty acid oxidation by globular adiponectin in cultured human skeletal muscle of obese type 2 diabetics. J. Clin. Endocrinol. Metab. 2005, 90, 3665-3672. [CrossRef]

143. Hamrick, M.; Dukes, A.; Arounleut, P.; Davis, C.; Periyasamy-Thandavan, S.; Mörk, S.; Herberg, S.; Johnson, M.; Isales, C.; Hill, W; et al. The adipokine leptin mediates muscle- and liver-derived IGF-1 in aged mice. Exp. Gerontol. 2015, 70, 92-96. [CrossRef]

144. Yvan-Charvet, L.; Quignard-Boulangé, A. Role of adipose tissue renin-angiotensin system in metabolic and inflammatory diseases associated with obesity. Kidney Int. 2011, 79, 162-168. [CrossRef]

145. Sowers, J.R.; Whaley-Connell, A.; Epstein, M. Narrative review: The emerging clinical implications of the role of aldosterone in the metabolic syndrome and resistant hypertension. Ann. Intern. Med. 2009, 150, 776-783. [CrossRef] [PubMed]

146. Wei, Y.; Clark, S.E.; Morris, E.M.; Thyfault, J.P.; Uptergrove, G.M.; Whaley-Connell, A.T.; Ferrario, C.M.; Sowers, J.R.; Ibdah, J.A. Angiotensin II-induced non-alcoholic fatty liver disease is mediated by oxidative stress in transgenic TG(mRen2)27(Ren2) rats. J. Hepatol. 2008, 49, 417-428. [CrossRef]

147. Yoshida, T.; Delafontaine, P. Mechanisms of Cachexia in Chronic Disease States. Am. J. Med. Sci. 2015, 350, 250-256. [CrossRef] [PubMed]

148. Bhanji, R.A.; Narayanan, P.; Allen, A.M.; Malhi, H.; Watt, K.D. Sarcopenia in hiding: The risk and consequence of underestimating muscle dysfunction in nonalcoholic steatohepatitis. Hepatology 2017, 66, 2055-2065. [CrossRef] [PubMed]

149. Suzuki, S.T.; Zhao, B.; Yang, J. Enhanced muscle by myostatin propeptide increases adipose tissue adiponectin, PPAR- $\alpha$, and PPAR- $\gamma$ expressions. Biochem. Biophys. Res. Commun. 2008, 369, 767-773. [CrossRef] [PubMed]

150. Dasarathy, $\mathrm{S}$. Is the adiponectin-AMPK-mitochondrial axis involved in progression of nonalcoholic fatty liver disease? Hepatology 2014, 60, 22-25. [CrossRef] [PubMed]

151. Zhang, C.; McFarlane, C.; Lokireddy, S.; Bonala, S.; Ge, X.; Masuda, S.; Gluckman, P.D.; Sharma, M.; Kambadur, R. Myostatindeficient mice exhibit reduced insulin resistance through activating the AMP-activated protein kinase signalling pathway. Diabetology 2011, 54, 1491-1501. [CrossRef]

152. Lee, H.J.; Lee, J.O.; Kim, N.; Kim, J.K.; Kim, H.I.; Lee, Y.W.; Kim, S.J.; Choi, J.-I.; Oh, Y.; Kim, J.H.; et al. Irisin, a Novel Myokine, Regulates Glucose Uptake in Skeletal Muscle Cells via AMPK. Mol. Endocrinol. 2015, 29, 873-881. [CrossRef] [PubMed]

153. Bostroem, P.; Wu, J.; Jedrychowski, M.P.; Korde, A.; Ye, L.; Lo, J.C.; Rasbach, K.A.; Bostroem, E.A.; Choi, J.H.; Long, J.Z.; et al. A PGC1- $\alpha$-dependent myokine that drives brown-fat-like development of white fat and thermogenesis. Nat. Cell Biol. 2012, 481, 463-468. [CrossRef] [PubMed]

154. Metwally, M.; Bayoumi, A.; Romero-Gomez, M.; Thabet, K.; John, M.; Adams, L.A.; Huo, X.; Aller, R.; García-Monzón, C.; Arias-Loste, M.T.; et al. A polymorphism in the Irisin-encoding gene (FNDC5) associates with hepatic steatosis by differential miRNA binding to the 3'UTR. J. Hepatol. 2019, 70, 494-500. [CrossRef]

155. Tajiri, K.; Shimizu, Y. Branched-chain amino acids in liver diseases. World J. Gastroenterol. 2013, 19, 7620-7629. [CrossRef] [PubMed]

156. Tsien, C.; Davuluri, G.; Singh, D.; Allawy, A.; Have, G.A.T.; Thapaliya, S.; Schulze, J.M.; Barnes, D.; McCullough, A.J.; Engelen, M.P.; et al. Metabolic and molecular responses to leucine-enriched branched chain amino acid supplementation in the skeletal muscle of alcoholic cirrhosis. Hepatology 2015, 61, 2018-2029. [CrossRef]

157. Shangraw, R.E.; Jahoor, F. Effect of liver disease and transplantation on urea synthesis in humans: Relationship to acid-base status. Am. J. Physiol. Liver Physiol. 1999, 276, G1145-G1152. [CrossRef] [PubMed]

158. Dam, G.; Ott, P.; Aagaard, N.K.; Vilstrup, H. Branched-chain amino acids and muscle ammonia detoxification in cirrhosis. Metab. Brain Dis. 2013, 28, 217-220. [CrossRef]

159. Holecek, M. Evidence of a vicious cycle in glutamine synthesis and breakdown in pathogenesis of hepatic encephalopathytherapeutic perspectives. Metab. Brain Dis. 2013, 29, 9-17. [CrossRef]

160. Lockwood, A.H.; McDonald, J.M.; Reiman, R.E.; Gelbard, A.S.; Laughlin, J.S.; Duffy, T.E.; Plum, F. The dynamics of ammonia metabolism in man. Effects of liver disease and hyperammonemia. J. Clin. Investig. 1979, 63, 449-460. [CrossRef]

161. Dasarathy, S. Myostatin and beyond in cirrhosis: All roads lead to sarcopenia. J. Cachex-Sarcopenia Muscle 2017, 8, 864-869. [CrossRef]

162. Dasarathy, S.; Muc, S.; Hisamuddin, K.; Edmison, J.M.; Dodig, M.; McCullough, A.J.; Kalhan, S.C. Altered expression of genes regulating skeletal muscle mass in the portacaval anastamosis rat. Am. J. Physiol. Liver Physiol. 2007, 292, G1105-G1113. [CrossRef]

163. Dasarathy, S.; McCullough, A.J.; Muc, S.; Schneyer, A.; Bennett, C.D.; Dodig, M.; Kalhan, S.C. Sarcopenia associated with portosystemic shunting is reversed by follistatin. J. Hepatol. 2011, 54, 915-921. [CrossRef] [PubMed]

164. Qiu, J.; Tsien, C.; Thapalaya, S.; Narayanan, A.; Weihl, C.C.; Ching, J.K.; Eghtesad, B.; Singh, K.; Fu, X.; Dubyak, G.; et al. Hyperammonemia-mediated autophagy in skeletal muscle contributes to sarcopenia of cirrhosis. Am. J. Physiol. Metab. 2012, 303, E983-E993. [CrossRef] [PubMed]

165. Qiu, J.; Thapaliya, S.; Runkana, A.; Yang, Y.; Tsien, C.; Mohan, M.L.; Narayanan, A.; Eghtesad, B.; Mozdziak, P.E.; McDonald, C.; et al. Hyperammonemia in cirrhosis induces transcriptional regulation of myostatin by an NF- $\mathrm{kB}-\mathrm{mediated}$ mechanism. Proc. Natl. Acad. Sci. USA 2013, 110, 18162-18167. [CrossRef]

166. Kosenko, E.; Venediktova, N.; Kaminsky, Y.; Montoliu, C.; Felipo, V. Sources of oxygen radicals in brain in acute ammonia intoxication in vivo. Brain Res. 2003, 981, 193-200. [CrossRef] 
167. Holeček, M. Branched-chain amino acid supplementation in treatment of liver cirrhosis: Updated views on how to attenuate their harmful effects on cataplerosis and ammonia formation. Nutrient 2017, 41, 80-85. [CrossRef] [PubMed]

168. Owen, O.E.; Kalhan, S.C.; Hanson, R.W. The Key Role of Anaplerosis and Cataplerosis for Citric Acid Cycle Function. J. Biol. Chem. 2002, 277, 30409-30412. [CrossRef]

169. Davuluri, G.; Allawy, A.; Thapaliya, S.; Rennison, J.H.; Singh, D.; Kumar, A.; Sandlers, Y.; Van Wagoner, D.R.; Flask, C.A.; Hoppel, C.; et al. Hyperammonaemia-induced skeletal muscle mitochondrial dysfunction results in cataplerosis and oxidative stress. J. Physiol. 2016, 594, 7341-7360. [CrossRef]

170. McDaniel, J.G.; Davuluri, G.; Hill, E.A.; Moyer, M.; Runkana, A.; Prayson, R.; Van Lunteren, E.; Dasarathy, S. Hyperammonemia results in reduced muscle function independent of muscle mass. Am. J. Physiol. Gastrointest. Liver Physiol. 2016, 310, G163-G170. [CrossRef]

171. Davuluri, G.; Krokowski, D.; Guan, B.-J.; Kumar, A.; Thapaliya, S.; Singh, D.; Hatzoglou, M.; Dasarathy, S. Metabolic adaptation of skeletal muscle to hyperammonemia drives the beneficial effects of l-leucine in cirrhosis. J. Hepatol. 2016, 65, 929-937. [CrossRef] [PubMed]

172. Harding, H.P.; Novoa, I.; Zhang, Y.; Zeng, H.; Wek, R.; Schapira, M.; Ron, D. Regulated Translation Initiation Controls StressInduced Gene Expression in Mammalian Cells. Mol. Cell 2000, 6, 1099-1108. [CrossRef]

173. Plauth, M.; Egberts, E.H.; Abele, R.; Müller, P.H.; Fürst, P. Characteristic pattern of free amino acids in plasma and skeletal muscle in stable hepatic cirrhosis. Hepatogastroenterology 1990, 37, 135-139. [PubMed]

174. Montanari, A.; Simoni, I.; Vallisa, D.; Trifirò, A.; Colla, R.; Abbiati, R.; Borghi, L.; Novarini, A. Free amino acids in plasma and skeletal muscle of patients with liver cirrhosis. Hepatology 1988, 8, 1034-1039. [CrossRef]

175. Grossmann, M.; Hoermann, R.; Gani, L.; Chan, I.; Cheung, A.; Gow, P.J.; Li, A.; Zajac, J.D.; Angus, P. Low testosterone levels as an independent predictor of mortality in men with chronic liver disease. Clin. Endocrinol. 2012, 77, 323-328. [CrossRef] [PubMed]

176. Orr, R.; Singh, M.F. The anabolic androgenic steroid oxandrolone in the treatment of wasting and catabolic disorders: Review of efficacy and safety. Drugs 2004, 64, 725-750. [CrossRef]

177. Liu, W.; Thomas, S.G.; Asa, S.L.; Gonzalez-Cadavid, N.; Bhasin, S.; Ezzat, S. Myostatin Is a Skeletal Muscle Target of Growth Hormone Anabolic Action. J. Clin. Endocrinol. Metab. 2003, 88, 5490-5496. [CrossRef]

178. Lakshman, K.M.; Bhasin, S.; Corcoran, C.; Collins-Racie, L.A.; Tchistiakova, L.; Forlow, S.B.; Ledger, K.S.; Burczynski, M.E.; Dorner, A.J.; LaVallie, E.R. Measurement of myostatin concentrations in human serum: Circulating concentrations in young and older men and effects of testosterone administration. Mol. Cell. Endocrinol. 2009, 302, 26-32. [CrossRef] [PubMed]

179. Dasarathy, S.; Mullen, K.D.; Dodig, M.; Donofrio, B.; McCullough, A.J. Inhibition of aromatase improves nutritional status following portacaval anastomosis in male rats. J. Hepatol. 2006, 45, 214-220. [CrossRef] [PubMed]

180. Bloemen, J.G.; Damink, S.W.O.; Venema, K.; Buurman, W.A.; Jalan, R.; Dejong, C.H. Short chain fatty acids exchange: Is the cirrhotic, dysfunctional liver still able to clear them? Clin. Nutr. 2010, 29, 365-369. [CrossRef] [PubMed]

181. Rainer, F.; Horvath, A.; Sandahl, T.D.; Leber, B.; Schmerboeck, B.; Blesl, A.; Groselj-Strele, A.; Stauber, R.E.; Fickert, P.; Stiegler, P.; et al. Soluble CD163 and soluble mannose receptor predict survival and decompensation in patients with liver cirrhosis, and correlate with gut permeability and bacterial translocation. Aliment. Pharmacol. Ther. 2018, 47, 657-664. [CrossRef]

182. Elswefy, S.E.-S.; Abdallah, F.R.; Atteia, H.H.; Wahba, A.S.; Hasan, R.A. Inflammation, oxidative stress and apoptosis cascade implications in bisphenol A-induced liver fibrosis in male rats. Int. J. Exp. Pathol. 2016, 97, 369-379. [CrossRef]

183. Nishikawa, H.; Enomoto, H.; Nishiguchi, S.; Iijima, H. Liver Cirrhosis and Sarcopenia from the Viewpoint of Dysbiosis. Int. J. Mol. Sci. 2020, 21, 5254. [CrossRef]

184. Huo, Y.R.; Suriyaarachchi, P.; Gomez, F.; Curcio, C.L.; Boersma, D.; Muir, S.W.; Montero-Odasso, M.; Gunawardene, P.; Demontiero, O.; Duque, G. Phenotype of Osteosarcopenia in Older Individuals with a History of Falling. J. Am. Med. Dir. Assoc. 2015, 16, 290-295. [CrossRef] [PubMed]

185. Hayashi, M.; Abe, K.; Fujita, M.; Okai, K.; Takahashi, A.; Ohira, H. Association between sarcopenia and osteoporosis in chronic liver disease. Hepatol. Res. 2018, 48, 893-904. [CrossRef]

186. Hayashi, F.; Kaibori, M.; Sakaguchi, T.; Matsui, K.; Ishizaki, M.; Kwon, A.-H.; Iwasaka, J.; Kimura, Y.; Habu, D. Loss of skeletal muscle mass in patients with chronic liver disease is related to decrease in bone mineral density and exercise tolerance. Hepatol. Res. 2018, 48, 345-354. [CrossRef] [PubMed]

187. Bering, T.; Diniz, K.G.; Coelho, M.P.P.; Vieira, D.A.; Soares, M.M.S.; Kakehasi, A.M.; Correia, M.I.T.; Teixeira, R.; Queiroz, D.M.; Rocha, G.A.; et al. Association between pre-sarcopenia, sarcopenia, and bone mineral density in patients with chronic hepatitis C. J. Cachex-Sarcopenia Muscle 2018, 9, 255-268. [CrossRef]

188. Santos, L.A.A.; Lima, T.B.; Augusti, L.; Franzoni, L.D.C.; Yamashiro, F.D.S.; Bolfi, F.; Nunes, V.D.S.; Dorna, M.D.S.; De Oliveira, C.V.; Caramori, C.A.; et al. Handgrip strength as a predictor of bone mineral density in outpatients with cirrhosis. J. Gastroenterol. Hepatol. 2015, 31, 229-234. [CrossRef] [PubMed]

189. Saeki, C.; Kanai, T.; Nakano, M.; Oikawa, T.; Torisu, Y.; Abo, M.; Saruta, M.; Tsubota, A. Relationship between Osteosarcopenia and Frailty in Patients with Chronic Liver Disease. J. Clin. Med. 2020, 9, 2381. [CrossRef] [PubMed]

190. Saeki, C.; Takano, K.; Oikawa, T.; Aoki, Y.; Kanai, T.; Takakura, K.; Nakano, M.; Torisu, Y.; Sasaki, N.; Abo, M.; et al. Comparative assessment of sarcopenia using the JSH, AWGS, and EWGSOP2 criteria and the relationship between sarcopenia, osteoporosis, and osteosarcopenia in patients with liver cirrhosis. BMC Musculoskelet. Disord. 2019, 20, 1-12. [CrossRef]

191. Karasik, D.; Cohen-Zinder, M. The genetic pleiotropy of musculoskeletal aging. Front. Physiol. 2012, 3, 303. [CrossRef] 
192. Guo, Y.-F.; Zhang, L.-S.; Liu, Y.-J.; Hu, H.-G.; Li, J.; Tian, Q.; Yu, P.; Zhang, F.; Yang, T.-L.; Peng, X.-L.; et al. Suggestion of GLYAT gene underlying variation of bone size and body lean mass as revealed by a bivariate genome-wide association study. Qual. Life Res. 2012, 132, 189-199. [CrossRef] [PubMed]

193. Huang, J.; Hsu, Y.-H.; Mo, C.; Abreu, E.; Kiel, D.P.; Bonewald, L.F.; Brotto, M.; Karasik, D. METTL21CIs a Potential Pleiotropic Gene for Osteoporosis and Sarcopenia Acting Through the Modulation of the NF-kB Signaling Pathway. J. Bone Miner. Res. 2014, 29, 1531-1540. [CrossRef] [PubMed]

194. Edmondson, D.G.; Lyons, G.E.; Martin, J.F.; Olson, E.N. Mef2 gene expression marks the cardiac and skeletal muscle lineages during mouse embryogenesis. Development 1994, 120, 1251-1263. [PubMed]

195. Kramer, I.; Baertschi, S.; Halleux, C.; Keller, H.; Kneissel, M. Mef2cdeletion in osteocytes results in increased bone mass. J. Bone Miner. Res. 2012, 27, 360-373. [CrossRef]

196. Hamrick, M.W. The skeletal muscle secretome: An emerging player in muscle-bone crosstalk. BoneKEy Rep. 2012, 1, 60. [CrossRef]

197. Dankbar, B.; Fennen, M.; Brunert, D.; Hayer, S.; Frank, S.; Wehmeyer, C.; Beckmann, D.; Paruzel, P.; Bertrand, J.; Redlich, K.; et al. Myostatin is a direct regulator of osteoclast differentiation and its inhibition reduces inflammatory joint destruction in mice. Nat. Med. 2015, 21, 1085-1090. [CrossRef]

198. Puolakkainen, T.; Ma, H.; Kainulainen, H.; Pasternack, A.; Rantalainen, T.; Ritvos, O.; Heikinheimo, K.; Hulmi, J.J.; Kiviranta, R. Treatment with soluble activin type IIB-receptor improves bone mass and strength in a mouse model of Duchenne muscular dystrophy. BMC Musculoskelet. Disord. 2017, 18, 20. [CrossRef]

199. DiGirolamo, D.J.; Singhal, V.; Chang, X.; Lee, S.-J.; Germain-Lee, E.L. Administration of soluble activin receptor 2B increases bone and muscle mass in a mouse model of osteogenesis imperfecta. Bone Res. 2015, 3, 14042. [CrossRef] [PubMed]

200. Hamrick, M.; Shi, X.; Zhang, W.; Pennington, C.; Thakore, H.; Haque, M.; Kang, B.; Isales, C.; Fulzele, S.; Wenger, K. Loss of myostatin (GDF8) function increases osteogenic differentiation of bone marrow-derived mesenchymal stem cells but the osteogenic effect is ablated with unloading. Bone 2007, 40, 1544-1553. [CrossRef]

201. Colaianni, G.; Cuscito, C.; Mongelli, T.; Oranger, A.; Mori, G.; Brunetti, G.; Colucci, S.; Cinti, S.; Grano, M. Irisin Enhances Osteoblast Differentiation In Vitro. Int. J. Endocrinol. 2014, 2014, 902186. [CrossRef] [PubMed]

202. Colaianni, G.; Cuscito, C.; Mongelli, T.; Pignataro, P.; Buccoliero, C.; Liu, P.; Lu, P.; Sartini, L.; Di Comite, M.; Mori, G.; et al. The myokine irisin increases cortical bone mass. Proc. Natl. Acad. Sci. USA 2015, 112, 12157-12162. [CrossRef]

203. Kitase, Y.; Vallejo, J.A.; Gutheil, W.; Vemula, H.; Jähn, K.; Yi, J.; Zhou, J.; Brotto, M.; Bonewald, L.F. $\beta$-aminoisobutyric Acid, 1-BAIBA, Is a Muscle-Derived Osteocyte Survival Factor. Cell Rep. 2018, 22, 1531-1544. [CrossRef]

204. Karsenty, G.; Ferron, M. The contribution of bone to whole-organism physiology. Nat. Cell Biol. 2012, 481, 314-320. [CrossRef]

205. Mera, P.; Laue, K.; Ferron, M.; Confavreux, C.; Wei, J.; Galán-Díez, M.; Lacampagne, A.; Mitchell, S.J.; Mattison, J.A.; Chen, Y.; et al. Osteocalcin Signaling in Myofibers Is Necessary and Sufficient for Optimum Adaptation to Exercise. Cell Metab. 2016, 23, 1078-1092. [CrossRef] [PubMed]

206. Dufresne, S.S.; Dumont, N.A.; Boulanger-Piette, A.; Fajardo, V.A.; Gamu, D.; Kake-Guena, S.A.; David, R.O.; Bouchard, P.; Lavergne, É.; Penninger, J.M.; et al. Muscle RANK is a key regulator of Ca2+ storage, SERCA activity, and function of fast-twitch skeletal muscles. Am. J. Physiol. Physiol. 2016, 310, C663-C672. [CrossRef]

207. Bonnet, N.; Bourgoin, L.; Biver, E.; Douni, E.; Ferrari, S. RANKL inhibition improves muscle strength and insulin sensitivity and restores bone mass. J. Clin. Investig. 2019, 129, 3214-3223. [CrossRef]

208. Dole, N.S.; Mazur, C.M.; Acevedo, C.; Lopez, J.P.; Monteiro, D.A.; Fowler, T.W.; Gludovatz, B.; Walsh, F.; Regan, J.N.; Messina, S.; et al. Osteocyte-Intrinsic TGF- $\beta$ Signaling Regulates Bone Quality through Perilacunar/Canalicular Remodeling. Cell Rep. 2017, 21, 2585-2596. [CrossRef]

209. Waning, D.L.; Mohammad, K.S.; Reiken, S.; Xie, W.; Andersson, D.C.; John, S.K.; Chiechi, A.; Wright, L.E.; Umanskaya, A.; Niewolna, M.; et al. Excess TGF- $\beta$ mediates muscle weakness associated with bone metastases in mice. Nat. Med. 2015, 21, 1262-1271. [CrossRef] [PubMed]

210. Bonewald, L.F.; Johnson, M.L. Osteocytes, mechanosensing and Wnt signaling. Bone 2008, 42, 606-615. [CrossRef]

211. Baron, R.; Kneissel, M. WNT signaling in bone homeostasis and disease: From human mutations to treatments. Nat. Med. 2013, 19, 179-192. [CrossRef] [PubMed]

212. Clevers, H.; Nusse, R. Wnt/ $\beta$-catenin signaling and disease. Cell 2012, 149, 1192-1205. [CrossRef] [PubMed]

213. Von Maltzahn, J.; Chang, N.C.; Bentzinger, C.F.; Rudnicki, M.A. Wnt signaling in myogenesis. Trends Cell Biol. $2012,22,602-609$. [CrossRef]

214. Huang, J.; Romero-Suarez, S.; Lara, N.; Mo, C.; Kaja, S.; Brotto, L.; Dallas, S.L.; Johnson, M.L.; Jähn, K.; Bonewald, L.F.; et al. Crosstalk Between MLO-Y4 Osteocytes and C2C12 Muscle Cells Is Mediated by the Wnt/ $\beta$-Catenin Pathway. JBMR Plus 2017, 1, 86-100. [CrossRef] [PubMed]

215. Strope, M.A.; Nigh, P.; Carter, M.I.; Lin, N.; Jiang, J.; Hinton, P.S. Physical Activity-Associated Bone Loading During Adolescence and Young Adulthood Is Positively Associated with Adult Bone Mineral Density in Men. Am. J. Men's Health 2014, 9, 442-450. [CrossRef]

216. De Kam, D.; Smulders, E.; Weerdesteyn, V.; Smits-Engelsman, B.C.M. Exercise interventions to reduce fall-related fractures and their risk factors in individuals with low bone density: A systematic review of randomized controlled trials. Osteoporos. Int. 2009, 20, 2111-2125. [CrossRef] 
217. Kirk, B.; Mooney, K.; Amirabdollahian, F.; Khaiyat, O. Exercise and Dietary-Protein as a Countermeasure to Skeletal Muscle Weakness: Liverpool Hope University-Sarcopenia Aging Trial (LHU-SAT). Front. Physiol. 2019, 10, 445. [CrossRef]

218. Kirk, B.; Mooney, K.; Cousins, R.; Angell, P.; Jackson, M.; Pugh, J.N.; Coyles, G.; Amirabdollahian, F.; Khaiyat, O. Effects of exercise and whey protein on muscle mass, fat mass, myoelectrical muscle fatigue and health-related quality of life in older adults: A secondary analysis of the Liverpool Hope University-Sarcopenia Ageing Trial (LHU-SAT). Graefe's Arch. Clin. Exp. Ophthalmol. 2020, 120, 493-503. [CrossRef] [PubMed]

219. Román, E.; Torrades, M.T.; Nadal, M.J.; Cárdenas, G.; Nieto, J.C.; Vidal, S.; Bascuñana, H.; Juárez, C.; Guarner, C.; Córdoba, J.; et al. Randomized Pilot Study: Effects of an Exercise Programme and Leucine Supplementation in Patients with Cirrhosis. Dig. Dis. Sci. 2014, 59, 1966-1975. [CrossRef]

220. Kitajima, Y.; Takahashi, H.; Akiyama, T.; Murayama, K.; Iwane, S.; Kuwashiro, T.; Tanaka, K.; Kawazoe, S.; Ono, N.; Eguchi, T.; et al. Supplementation with branched-chain amino acids ameliorates hypoalbuminemia, prevents sarcopenia, and reduces fat accumulation in the skeletal muscles of patients with liver cirrhosis. J. Gastroenterol. 2017, 53, 427-437. [CrossRef]

221. Glass, D.J. Molecular mechanisms modulating muscle mass. Trends Mol. Med. 2003, 9, 344-350. [CrossRef]

222. Dukes, A.; Davis, C.; El Refaey, M.; Upadhyay, S.; Mork, S.; Arounleut, P.; Johnson, M.H.; Hill, W.D.; Isales, C.M.; Hamrick, M.W. The aromatic amino acid tryptophan stimulates skeletal muscle IGF1/p70s6k/mTor signaling in vivo and the expression of myogenic genes in vitro. Nutrient 2015, 31, 1018-1024. [CrossRef] [PubMed]

223. Lin, F.D.; Smith, T.K.; Bayley, H.S. A Role for Tryptophan in Regulation of Protein Synthesis in Porcine Muscle. J. Nutr. 1988, 118, 445-449. [CrossRef]

224. Cruzat, V.; Rogero, M.M.; Keane, K.N.; Curi, R.; Newsholme, P. Glutamine: Metabolism and Immune Function, Supplementation and Clinical Translation. Nutrients 2018, 10, 1564. [CrossRef]

225. Mignon, M.; Beaufrère, A.-M.; Combaret, L.; Meynial-Denis, D. Does Long-Term Intermittent Treatment with Glutamine Improve the Well-being of Fed and Fasted Very Old Rats? J. Parenter. Enter. Nutr. 2007, 31, 456-462. [CrossRef]

226. Meynial-Denis, D. Glutamine metabolism in advanced age. Nutr. Rev. 2016, 74, 225-236. [CrossRef] [PubMed]

227. Zanker, J.; Duque, G. Osteoporosis in Older Persons: Old and New Players. J. Am. Geriatr. Soc. 2018, 67, 831-840. [CrossRef]

228. Kumar, A.; Davuluri, G.; DeSilva, R.N.; Engelen, M.P.; Have, G.A.T.; Prayson, R.; Deutz, N.E.; Dasarathy, S. Ammonia lowering reverses sarcopenia of cirrhosis by restoring skeletal muscle proteostasis. Hepatology 2017, 65, 2045-2058. [CrossRef]

229. Rose, C.F. Ammonia-Lowering Strategies for the Treatment of Hepatic Encephalopathy. Clin. Pharmacol. Ther. 2012, 92, 321-331. [CrossRef] [PubMed]

230. Phu, S.; Hassan, E.B.; Vogrin, S.; Kirk, B.; Duque, G. Effect of Denosumab on Falls, Muscle Strength, and Function in CommunityDwelling Older Adults. J. Am. Geriatr. Soc. 2019, 67, 2660-2661. [CrossRef]

231. Narayanan, R.; Coss, C.C.; Dalton, J.T. Development of selective androgen receptor modulators (SARMs). Mol. Cell. Endocrinol. 2018, 465, 134-142. [CrossRef]

232. Attie, K.M.; Borgstein, N.G.; Yang, Y.; Condon, C.H.; Wilson, D.M.; Pearsall, A.E.; Kumar, R.; Willins, D.A.; Seehra, J.S.; Sherman, M.L. A single ascending-dose study of muscle regulator ace-031 in healthy volunteers. Muscle Nerve 2013, 47, 416-423. [CrossRef] [PubMed]

233. Becker, C.; Lord, S.R.; Studenski, S.A.; Warden, S.J.; Fielding, R.A.; Recknor, C.P.; Hochberg, M.C.; Ferrari, S.L.; Blain, H.; Binder, E.F.; et al. Myostatin antibody (LY2495655) in older weak fallers: A proof-of-concept, randomised, phase 2 trial. Lancet Diabetes Endocrinol. 2015, 3, 948-957. [CrossRef]

234. Parise, G.; Snijders, T. Myostatin inhibition for treatment of sarcopenia. Lancet Diabetes Endocrinol. 2015, 3, 917-918. [CrossRef] 